\title{
KARA ARAÇLARI KASKO SİGORTASI GENEL ŞARTLARI VE YÜRÜRLÜKTE BULUNAN MEVZUAT HÜKÜMLERİ KAPSAMINDA YARGITAY'IN ALKOLLÜ ARAÇ KULLANIMI SIRASINDA MEYDANA GELEN ZARARLARA İLIŞKIIN YERLEŞİK KARARLARI ÜZERINE BİR İNCELEME
}

\author{
Burak DOĞAN*
}

\begin{abstract}
$\ddot{O} Z$
Kara Araçları Kasko Sigortası Genel Şartları'nda aynı zamanda sürücü olan sigorta ettirenin/sigortalının alkollü araç kullandı̆̆ sırada meydana gelen zararların sigortateminatı kapsamıdışındaolacağı hükümaltına alınmıştır. Bunagöre, alkollüaraç kullanımı sırasinda meydana gelen zararlar bakımından sigortacinın sorumluluğuna gidilemeyecektir. Söz konusu düzenleme yerleşik Yargıtay uygulamalarında lafzından farklı olacak şekilde, kazanın oluşumunda sigorta ettirenin/sigortalının tam kusurlu olmasl ve kazanin münhasiran alkolün etkisiyle meydana gelmesi şartiyla uygulanmaktadır. Illgili genel şart hükmüyle yerleşik Yargıtay uygulaması arasındaki bu çelişki, ilgili genel şart hükmünün kanunî dayanağı olan 2918 sayılı Karayolları Trafik Kanunu'nun 48'inci maddesinin birinci fikrası hükmünde 6487 sayll Kanun ile yapılan değişiklikle giderilmeye çalışılmıı̧tır. Buna rağmen Yargıtay, yerleşik uygulamasından vazgeçmeyerek münhasırlık ölçütünü uygulamaya devam etmektedir. Çalışmamızda ilgili genel şart hükmüyle yerleşik Yargitay uygulaması arasındaki bu farklllık ele alınarak, söz konusu çelişkinin sebepleri tespit edilerek, bu çelişkinin nasıl giderilebileceği hususunda çözüm önerileri ortaya konulmaktadır.
\end{abstract}

Anahtar Kelimeler: Alkollü Araç Kullanma, Sözleşmesel Görev, Teminat Dışl Kalan Hâller, Rizikonun Ağırlaşması, Münhasırlık Ölçütü.

* Arş. Gör. Dr., Ankara Hacı Bayram Veli Üniversitesi Hukuk Fakültesi, Ticaret Hukuku Anabilim Dalı, ANKARA, e-posta: burak.dogan@hbv.edu.tr

ORCID: 0000-0001-9066-4449

DOI : : 10.34246/ahbvuhfd.1065808

Yayın Kuruluna Ulaştığı Tarih $\quad$ :03/01/2022

Yayınlanmasının Uygun Görüldüğü Tarih: 10/01/2022 
Kara Araçları Kasko Sigortası Genel Şartları ve Yürürlükte Bulunan Mevzuat...

\title{
AN ASSESSMENT OF THE RULINGS OF TURKISH COURT OF APPEAL OVER THE LOSSES THAT OCCURS DURING THE COURSE OF DRIVING UNDER THE INFLUENCE OF ALCOHOL IN RESPECT OF GENERAL CONDITIONS OF LAND VEHICLES MOTOR INSURANCE AND CURRENT LEGISLATION
}

\begin{abstract}
In the General Conditions of Land Vehicles Motor Insurance, it is stipulated that the insured, who is also the driver, will not be covered by the insurance coverage for the damages that occur while driving while drunk. Accordingly, the insurer cannot be held liable for the damages that occur during drunk driving. The aforementioned regulation is applied differently from the wording of the established Turkish Court of Appeal practices, provided that the insured person is at fault in the occurrence of the accident and the accident occurs exclusively under the influence of alcohol. This contradiction between the relevant general condition provision and the established Supreme Court practice has been tried to be resolved by the amendment made with the Law No. 6487 of Article 48 of the Highway Traffic Law No. 2918, which is the legal basis of the relevant general condition provision. Despite this, Turkish Court of Appeal insists on applying the exclusivity criterion by not giving up its established practice. In our study, this difference between the relevant general condition provision and the established Turkish Court of Appeal practice is discussed, the causes of the said contradiction are determined, and solutions are offered on how to eliminate this contradiction.
\end{abstract}

Key Words: Driving Under the Influence of Alcohol, Contractual Obligation, Cases Out of Coverage, Aggravation of the Risk, Exclusivity Criterion.

\section{GİRIŞ}

Kara araçları kasko sigortası, hukukî niteliği itibariyle zarar sigortası mahiyetindeki aktif sigortaları kapsamında mütalâa edilen bir mal sigortasıdır ${ }^{1}$. Söz konusu sigorta sözleşmesiyle sigorta ettiren, kendisine yahut üçüncü kişiye ait olan aracın karayolunda sevk ve idaresi dolayısıyla araçta meydana gelebilecek muhtemel zararları muayyen bir sigortacı nezdinde teminat altına almaktadır. Bu sigorta türü bakımından sevk edilmiş olan ve bu mahiyetteki sigorta sözleşmelerinin eki olarak nitelendirebileceğimiz genel şartlar, Kara Araçları Kasko Sigortası Genel Şartları olarak isimlendirilmektedir.

1 Mal sigortaları için ayrıntılı bilgi için bkz. Mertol Can, Sigorta Hukuku Ders Kitabı, Genişletilmiş ve Gözden Geçirilmiş Üçüncü Bası, İmaj Yayınevi, 2009, s. 54-66. 
Söz konusu genel şartların "teminat dışında kalan zararlar” başlıklı A.5. maddesinde sigortacının sorumlu olmayacağı zarar türleri düzenlenmiş olup; bu başlık altında yer alan 5.5. maddesi uyarınca aracın, uyuşturucu madde veya 2918 sayılı Karayolları Trafik Kanunu uyarınca yasaklanan miktardan fazla içki almış kişiler tarafından kullanılması sırasında meydana gelebilecek zararların teminat kapsamı dışında oldukları düzenlenmiştir.

Kara Araçları Kasko Sigortası Genel Şartları'nın A.5 maddesinin 5.5. bendi hükmünün lafzına bakıldığında, alkollü araç kullanımı sırasında meydana gelen zararlar dolayısıyla, meydana gelen zarar ile alkollü araç kullanımı arasında illiyet bağı aranmaksızın, sigortacının sorumluluğu bulunmamaktadır. Sigortacının sorumluluktan kurtulabilmesi için alkollü araç kullanımının gerek aracı kullanan kişi, gerekse de üçüncü kişiler nezdinde yol açabileceği felâketler düşünüldüğünde, söz konusu genel şart hükmünün alkollü araç kullanımına dair pratiği önlemek adına caydırıcı ve adil bir netice öngördüğü düşünülebilir. Ne var ki, konuya ilişkin yerleşik Yargıtay uygulaması ile hükmün lafzı çelişmektedir. Zira Yargıtay, alkollü araç kullanımı sırasında meydana gelen zararların teminat kapsamı dışında bırakılabilmesi için kazanın münhasıran alkolün etkisinden ileri gelmiş olması şartını aramaktadır. Çalışmamızda, ilgili genel şart hükmünün lafzıyla yerleşik Yargıtay uygulaması arasındaki çelişkiyi tüm hatlarıyla ortaya koyarak, bu çelişkinin kaynağını ve nasıl giderilebileceğini münakaşa edeceğiz.

Önemle ifade etmeliyiz ki, çalışmamızda ortaya koyduğumuz sorun ve öneriler, uygun düştüğü ölçüde Kara Araçları Kasko Sigortası Genel Şartları'nın ehliyetsiz araç kullanımı sırasında meydana gelen zararların teminat kapsamı dışında olduğunu öngören A.5. maddesinin 5.4. bendi hükmü ve Karayolları Motorlu Araçlar Zorunlu Malî Sorumluluk Sigortası Genel Şartları'nın alkollü araç kullanımı sırasında meydana gelen zararlar bakımından sigortacının sigortalıya rücu hakkını öngören B.4.c. maddesi hükmü bakımından da cari olacaktır.

\section{Sigorta Genel Şartlarının Hukukî Mahiyeti}

Sigorta genel (umumî) şartları, hukukî mahiyeti itibariyle, her bir sigorta türü için ayrı olmak üzere evvelce hazırlanmış bulunan, sigorta sözleşmesinin eki mahiyetinde olan ve sigorta poliçesine eklenen standart hükümlerdir².

2 Rayegân Kender, Türkiye'de Hususî Sigorta Hukuku, Güncelleştirilmiș On Altıncı Bask1, On İki Levha Yayıncılık, 2017, s. 34; Şaban Kayıhan / Ömer Bağcı, Türk Özel Sigorta Hukuku Dersleri, Umuttepe Yayınevi, 2018, s. 106. 
Kara Araçları Kasko Sigortası Genel Şartları ve Yürürlükte Bulunan Mevzuat...

Nitekim 6102 say1lı Türk Ticaret Kanunu'nun 1425'inci maddesinde rahat ve kolay okunacak biçimde düzenlenmesi gereken sigorta poliçesinin, genel şartları da ihtiva etmesi gerektiği hüküm altına alınmıştır. Sigorta genel şartları, sigortac1 ile sigorta ettiren arasında münâkit olan sözleşmenin hükümleri arasında kabul edilir ve taraflar için bağlayıcılık taşır ${ }^{3}$. Bu anlamda genel şartlar, Kanunun emredici hükümlerinden sonra, fakat yardımcı hükümlerden önce gelir ve taraflar Kanuna aykırı olmayan genel şart hükümlerine riayet etmek zorundadirlar ${ }^{4}$.

Genel şartların hazırlayıcısının kim olduğuna dair Türk sigorta hukuku bakımından geçerli olan mevzuat hükümleri ve uygulama arasında çelişki bulunmaktadır. 5684 say1lı Sigortacılık Kanunu'nun 11'inci maddesinin birinci fıkrası hükmüne göre "Sigorta sözleşmelerinin ana muhtevası Müsteşarlıķ̧a onaylanan ve sigorta şirketlerince aynı şekilde uygulanacak olan genel şartlara göre düzenlenir." Söz konusu hükümde sigorta genel şartlarının kim tarafından hazırlanacağı belirtilmemiş, ancak bu şartların sigorta şirketlerini Devlet adına denetleyen makam tarafından onaylanacağı hükme bağlanmıştır. O hâlde mezkûr hükümden sigorta genel şartlarının sigorta şirketleri tarafından hazırlanacağ 1 sonucu çıkmaktadır ${ }^{6}$. Ancak uygulamada sigorta genel şartlarının hazırlanması işinin sigorta şirketlerine bırakılmadığı, genel şartların bizatihi ilgili Bakanlık tarafından hazırlandığı görülmektedir ${ }^{7}$. İlgili Bakanlık muayyen bir sigorta türüne ilişkin genel şartları hazırladıktan sonra ilgili genel şartlar Resmî Gazete'nin yönetmelikler kısmında yayınlanarak yürürlüğe girmektedir ${ }^{8}$.

Sözleşmenin eki mahiyetindeki genel şart hükümleri emredici Kanun hükümlerine aykırı olamazlar. Sigorta genel şartları, emredici Kanun hükümlerine aykırı olduğu takdirde hükümsüz addedilerek uygulanmaz' ${ }^{9}$ Bu

\footnotetext{
3 Kender, s. 74; Haydar Arseven, Sigorta Hukuku, Beta Yayınevi, 1991, s. 32.

4 Arseven, s. 32.

55684 sayılı Kanunun yürürlüğe girdiği tarihte sigorta genel şartları Hazine Müsteşarlığ tarafindan onaylanmaktaydı. Ancak sigorta genel şartları günümüzde Gümrük ve Ticaret Bakanlığ

6 Kender, s. 74.

Kender, s. 314; Can, s. 260.

8 Can, s. 260.

9 Can, s. 261; Arseven, s. 33; Kayıhan / Bağc1, s. 106.
} 
durumda genel şartlar yerine Kanun hükümleri uygulanacaktır ${ }^{10}$.

\section{Alkollü Araç Kullanımına İlişkin Mevzuat Hükümleri ve Kara Araçları Kasko Sigortası Genel Şartları}

Alkollü araç kullanımı, mevzuatımızda cezaî yönden 5237 sayılı Türk Ceza Kanunu'nda ve sigorta uyuşmazlıkları bakımından da esas alınmak üzere idarî yönden 2918 sayılı Karayolları Trafik Kanunu'nda düzenlenmiştir. Türk Ceza Kanunu'nun 179'uncu maddesinin üçüncü fikrası hükmü uyarınca, "Alkol veya uyuşturucu madde etkisiyle ya da başka bir nedenle emniyetli bir şekilde araç sevk ve idare edemeyecek hâlde olmasına rağmen araç kullanan kişi..." hakkında üç aydan iki yıla kadar hapis cezası verilir. Bu anlamda alkollü olması emniyetli bir şekilde araç kullanmasını engellediği hâlde araç kullanan kişi Türk Ceza Kanunu anlamında suç işlemektedir. Ancak bizi meselenin cezaî boyutundan ziyade sigorta uyuşmazlıklarına yansıyan kısmı ilgilendirmektedir.

2918 sayıl1 Karayolları Trafik Kanunu’nun 24 Mayıs 2013 tarihli ve 6487 sayılı Kanun ile değişik ${ }^{11}$ 48'inci maddesinin birinci fikrası, "uyuşturucu ve uyarıcı maddeleri almış olan sürücülerile alkollü olan sürücülerin karayolunda araç sürmeleri yasaktır.” hükmünü ihtiva etmektedir. Görüldüğü üzere, salt alkollü araç kullanımı, başkaca bir şart aranmaksızın ilgili fikra hükmüyle yasaklanmıştır. 24 Mayıs 2013 tarihli değişiklikten önce Karayolları Trafik Kanunu'nun 48'inci maddesinin birinci fikrası şöyleydi: "Uyuşturucu veya keyif verici maddeleri almış olanlar ile alkollü içki almış olması nedeniyle güvenli sürme yeteneklerini kaybetmiş kişilerin karayolunda araç sürmeleri yasaktır." Bu anlamda bahse konu değişiklikten önce yasağın kapsamında tek başına alkollü içki almış olanlar kişiler değil, alkollü içki almış olmaları nedeniyle güvenli sürüş yeteneğini kaybetmiş kişilerdi. Diğer bir ifadeyle, bir kimsenin alkollü olması tek başına yasağın ihlâl edilmiş olduğu anlamına gelmiyor, ayrıca kişinin güvenli sürüş yeteneğini kaybetmiş olup olmadığ tetkik ediliyordu. Ancak 6487 sayılı Kanun'un getirdiği değişiklikle beraber sürücünün alkollü olması yasağın ihlâli için tek başına yeterli görülmüştür. Kanun Koyucunun bu değişikliği yapmasına âmil olan saik, kanaatimizce, alkollü bir sürücünün güvenli sürüş yeteneğini kaybetmiş olup olmadığına dair ispat güçlüğüdür. Kanun Koyucu bu değişiklikle birlikte bu husustaki

\footnotetext{
10 Ali Bozer, Sigorta Hukuku, BTHAE Yayınevi, 1965, s. 135.

11 İlgili değişiklik 11 Haziran 2013 tarihinde Resmî Gazete'de yayımlanarak yürürlüğe girmiştir.
} 
Kara Araçları Kasko Sigortası Genel Şartları ve Yürürlükte Bulunan Mevzuat...

ispat yükünü ortadan kaldırarak, yasal haddi aşan düzeyde alkollü olan sürücünün güvenli sürüş yeteneğini de kaybetmiş sayılacağını aksi iddia ve ispat edilemez kesin bir karine olarak düzenlemiş, böylelikle uygulamada bu yüzden ortaya çıkan sorunları ve tereddütleri gidermeyi amaçlamışıır ${ }^{12}$.

'Alkollü sürücü' tabiri ile anlaşılması gerekenin ne olduğu, aynı maddenin beşinci fikra hükmünde belirtilmiştir. $\mathrm{Bu}$ fikra hükmüne göre karayolunda seyreden bir araç sürücüsünün KTK m. 48/1 anlamında alkollü kabul edilebilmesi için hususî otomobil kullanıcıları bakımından 0.50 promilin, diğer araç kullanıcıları bakımından ise 0.20 promilin üzerinde alkol ölçümü yapılmış olmalıdır. Dolayısıyla 0.50 promilin üzerinde alkol almış olduğu tespit edilen hususî otomobil sürücüleri 'alkollü' kabul edilecektir'13. Alkol promil oranının nasıl tespit edileceği ise aynı maddenin ikinci fikrası hükmünde belirtilmiştir.

Karayolları Trafik Yönetmeliği'nin 19.02.2014 tarihli değişik 97'nci maddesi, 2918 sayıl1 Karayolları Trafik Kanunu'nun 48'inci maddesinin birinci fıkrası hükmüyle hemahenk olacak şekilde düzenlenmiş, kanlarındaki alkol miktarı 0.50 promilin üzerinde olan hususî otomobil kullanıcıları ile kanlarındaki alkol miktarı 0.20 promilin üzerinde olan diğer araç kullanıcılarının alkollü kabul edileceği, alkollü araç kullanmanın ise yasak olduğu hükme bağlanmıştır. Hemen ifade etmeliyiz ki, 6487 sayılı Kanun değişikliğinden evvel, sürücünün alkollü kabul edilebilmesi için aşılması gereken promil oranları yalnız adı geçen Yönetmelik'te belirtilmekteydi. Ancak 6487 sayılı Kanun değişikliğiyle beraber yasal haddi teşkil eden promil oranları 2918 sayılı Karayolları Trafik Kanunu'nun 48'inci maddesi hükmünde de düzenlenmiştir. Böylelikle, ilgili yönetmelik hükümlerine kanunî dayanak

12 Nitekim Alman sigorta hukuku uygulamasında da farklı promil miktarı üzerinden benzer bir yaklaşım kabul edilmiştir. Buna göre, kandaki alkol promil oranı 1,1'in üzerinde olan sürücülerin güvenli sürüş yeteneklerini kaybetmiş oldukları, aksi ispat edilemez biçimde kabul edilmektedir. Bu anlamda aynı kazayı hiç alkol almamış bir sürücünün de yapabileceği yönündeki 'teorik olasılık' savunmaması dinlenmemekte, somut olayın özelliklerini aksini açık bir şekilde ortaya koymadığı müddetçe kazanın alkol etkisinden kaynakladığına dair görüşüne dayalı varsayım kabul edilmektedir. Bkz. Samim Ünan, "Yargitay 17. Hukuk Dairesi'nin Araç Üzerindeki Rehin, Alkollü Araç Kullanılması ve Araçtaki Değer Kaybı” Sorunlarını Ele Alan Kara Araçları Kasko Sigortası ile İlgili 02.05.2013 Gün ve 2013/19986148 Sayılı Kararının Değerlendirilmesi”, 2013, 27, Ticaret Hukuku ve Yargıtay Kararları Sempozyumu, s. 132.

13 Türk Ceza Kanunu'nun 179'uncu maddesinin üçüncü fikrası uyarınca trafik güvenliğini tehlikeye sokma suçunun işlenebilmiş olması ve bu suça ilişkin cezanın verilebilmesi için ise kandaki alkol miktarının 1.00 promilin üzerinde olması icap etmektedir (KTK m. 5/6). 
tesis edilmiştir.

Kara Araçları Kasko Sigortası Genel Şartları'nın “Teminat Dışında Kalan Zararlar" başlıklı A.5. maddesinin 5.5. bendi uyarınca "Aracın, uyuşturucu madde veya Karayollar Trafik Yönetmeliğinde belirlenen seviyenin üzerinde alkollü içki almış kişilerce veya aynı mevzuatta alkollü içki alamayacağı belirtilen kişilerce alkollü içki alınmak suretiyle kullanılması sirasında meydana gelen zararlar..." dolayısıyla sigortacının sorumluluğu bulunmaktadır. Söz konusu maddenin yasal dayanağ 2918 sayılı Karayolları Trafik Kanunu'nun 48'inci maddesidir.

III. Konuya İlişkin Yargıtay Kararları ve Doktrinde Yöneltilen Eleştiriler

Yargıtay'ın Kara Araçları Kasko Sigortası Genel Şartları'nın A.5. maddesinin 5.5. bendinin uygulamasıyla ilgili istikrarlı kararları, sigorta şirketinin salt aynı zamanda sürücü olan sigorta ettirenin/sigortalının kaza esnasında alkollü olduğu gerekçeyle vâkizararı ödemekten imtinaedemeyeceği, sigorta şirketinin aynı zamanda kazanın münhasıran alkolün etkisiyle meydana gelmiş olduğunu da kanttlamakla mükellef olduğu yönündedir ${ }^{14}$. Buna göre, alkollü sürücünün zarara yol açan kazanın gerçekleşmesinde tam kusurlu

14 "Hasarın teminat dışı kalabilmesi için sürücünün sadece alkollü olması yetmeyip kazanın münhasıran alkolün etkisinde oluşması gerekmektedir. Üstelik böyle bir durumda hasarın teminat dışı kaldığının ispat yükü TTK>nin 1409'uncu maddesi (eTTK m. 1281) hükmü gereğince sigortacıya düşmektedir. Yargıtay'ın yerleşik uygulamalarında; sürücünün aldı̆̆ alkol oranının doğrudan doğruya sonuca etkisi bulunmadığından, kazanın salt alkolün etkisiyle gerçekleşip gerçekleşmediğinin, alkol dışında başka unsurların da olayın meydana gelmesinde rol oynayıp oynamadığının saptanması gerektiği benimsenmektedir. Kaza tespit tutanağında; sigortalı araç sürücüsüne kavşaklarda geçiş önceliğine uymadığından ve alkollü araç kullandı̆̆ından aslî, karşı araç sürücüsüne kavşağa yaklaşırken hızını azaltmadiğından talî kusur verilmişstir. Sigorta Tahkim Komisyonunca hükme esas alınan bilirkişi raporunda da; davacının maliki bulunduğu araç sürücüsünün kazanın meydana gelmesinde $\% 75$ oranında, karşı araç sürücüsünün,\%25 oranında kusurlu olduğu belirtildikten sonra, kazanın sigortalı araç sürücüsünün münhasıran alkollü olmasından meydana gelmediği ifade edilmiştir. Kaza sırasında sigortalı araç sürücüsünün 1.83 promil alkollü olduğu saptanmış ise de, sürücünün alkollü olması yalnız başına hasarın teminat dışı kalmasını gerektirmez. Kazanın salt alkolün etkisiyle oluşması ve başka etmenlerin bulunmaması gerekir. Dosya kapsamından ve bilirkişi raporlarından, davacıya ait araç sürücüsünün tek bașına kazaya sebebiyet vermediği, dava dışı sürücünün de ikinci derece (\%25) kusurlu davranışı ile olaya katılımının bulunduğu, dolayısıyla kazanın münhasıran alkolün etkisiyle meydana gelmediği anlaşılmaktadır. Bu durumda Bölge Adliye Mahkemesince, rizikonun teminat kapsamında kaldı̆̆ kabul edilerek, istinaf başvurusunun reddine karar vermek gerekir." Yargitay 17. HD., 2018 / 4623 E., 2018 / 11940 K., 10.12.2018, <www.kazanci.com.tr> Erişim Tarihi 28.12.2021. 
Kara Araçları Kasko Sigortası Genel Şartları ve Yürürlükte Bulunan Mevzuat...

olmas $1^{15}$ ve kusurun münhasıran sürücünün alkollü araç kullanmasından ileri gelmiş olması gerekmektedir. Buna göre, kazanın oluşumunda kazaya karışan diğer araç sürücüsünün de kusuru olduğu takdirde sigortacı ilgili genel şart hükmüne dayanarak sorumlulukta kurtulamaz. Esasen yukarıda söz edilen mevzuat değişikliğinden önce verilen bu yöndeki kararların hukukî dayanağı, 2918 sayılı Karayolları Trafik Kanunu'nun 48'inci maddesinin birinci fıkrasında yer alan 'güvenli sürüş yeteneğinin kaybı' şartı ve aynı zamanda alkol promil oranlarının Yönetmelik hükmünde belirlenmiş olmasıydı. Yargıtay, kişinin alkollü olduğunun kabulüyle ilgili yasal haddin Yönetmelik hükmüyle belirlenemeyeceğine, dolayısıyla Yönetmelikte belirlenmiş olan promil sınırlarına dayalı hüküm tesis edilemeyeceği yönünde kararlar vermekteydi. Yargıtay, 6102 sayılı Türk Ticaret Kanunu'nun 1409 (6762 sayılı eTTK m. 1281) hükmü uyarınca, kazanın münhasıran alkolün etkisiyle meydana gelmiş olduğunun ispatının sigortacıya ait olduğunu kabul etmektedir.

Doktrinde Yargıtay'ın bu yöndeki kararlarının 6487 sayılı Kanun değişikliğiyle birlikte değişmesi gerektiği, zira artık 2918 sayılı Karayolları Trafik Kanunu'nun 48'inci maddesinin birinci fikrasında hüküm altına alınmış olan alkollü araç kullanma yasağı için güvenli sürüş yeteneği kaybetme şartının aranmadığı, üstelik kişinin alkollü kabul edilebilmesi için aranan asgarî promil miktarının Kanunla belirlenmiş olduğu ileri sürülmüştür.

Seven, söz konusu değişiklikler sonrasında, sigortacının 6102 sayılı TTK m. 1409 hükmü uyarınca ispat yükünü yerine getirmiş sayılabilmesi için araç sürücüsünün 2918 sayılı KTK m. 48/1 belirtilen promil miktarını aşmış olduğunu ortaya koymasının artık yeterli olacağını ifade etmiştir ${ }^{16}$.

15 “...sigortalı araç sürücüsü kazadan sonra 04.25 'de yapılan ölçüme göre 0,85 promil alkollü olarak tespit edilmiştir. Ancak münhasırlıktan bahsedebilmek için kazaya neden olan başka etkenin olmaması gerekir. Oysa somut olayda, dosya kapsamına göre 6.5.2015 tarihli Trafik Ihtisas Dairesi raporunda davalı ZMSS'li sürücü ...'in \%70 oranında, dava dış1 araç sürücüsünün \%30 oranında kusurlu olduğu belirlenmiş, aldırılan hasar raporuna göre belirlenen miktarın davalının kusuruna tekabül eden kısmı için davanın kabulüne karar verilmiştir. Kazanın gerçekleşme şekline göre münhasırlıktan söz edilemez..." Yargıtay 17. HD., T., 2016 / 560 E., 2016 / 5641 K., 09.05.2016, <www.kazanci.com.tr> Erişim Tarihi 28.12.2021.

16 Vural Seven, “Alkollü Araç Kullanma İle İlgili Karayolları Trafik Kanunu'nda Yapılan Değişikliğin Sigorta Şirketinin İspat Yüküne Etkisi”, 2016, 22(3), Cevdet Yavuz’a Armağan, Marmara Üniversitesi Hukuk Fakültesi Hukuk Araştırmaları Dergisi, s. 2527. Buna karşıllık müellif, söz konusu değişiklikler sonrasında dahi yerleşik Yargıtay uygulamasında ortaya konulan münhasırlık ölçütüne halel gelmeyeceğini, dolayısıyla sigortacının tazminat ödeme borcundan kurtulabilmesi için halen kazanın münhasıran alkolün etkisiyle meydana gelmiş olduğunun ispatlanması gerektiğini ifade etmektedir. Bkz. Seven, s. 2528. 
Misili'nin Karayolları Motorlu Araçlar Zorunlu Malî Sorumluluk Sigortası Genel Şartları'nın alkollü araç kullanımı sırasında meydana gelen zararlar bakımından sigortacının sigortalıya rücu hakkını öngören B.4.c. bendine ilişkin mevzuat değişikliklerinden ${ }^{17}$ sonra ortaya çıkan yeni duruma ilişkin değerlendirmeleri, çalışmamızın konusunu teşkil eden Kara Araçları Kasko Sigortası Genel Şartları'nın A.5. maddesinin 5.5. bent hükmü hakkında da caridir. Misili, 2918 sayılı Karayolları Trafik Kanunu'nda ve ilgili genel şart hükümlerinde yapılan değişikliklerinden sonra, sigortacının sigortalıya rücu hakkının doğması yahut sigortacının sorumluluktan kurtulabilmesi için kazaya münhasıran alkolün sebebiyet vermesi şartının aranmaması gerektiğini, meydana gelen zarara sürücünün alkollü olması yanında başka bir etken de sebebiyet vermişse rücu hakkının kapsamının yahut ödenecek zararın miktarının alkolün etkisi nazara alınarak tespit edilmesi gerektiğini ifade etmiştir $^{18}$. Müellif ayrıca kazanın oluşumunda sürücünün yasal haddi aşan düzeyde alkollü olmasının hiçbir tesiri olmadığının ispatı halinde sigortacının ilgili genel şart hükümlerine dayanamayacağını ileri sürmüştür ${ }^{19}$. Son olarak müellif, kazaya alkollü olmasının müessir olmadığı hususunda ispat yükünün, 4721 sayılı Türk Medenî Kanunu'nun 6'ncı maddesi uyarınca, yasal haddi aşan düzeyde alkollü olduğu tespit edilen sigorta ettirene/sigortalıya ait olduğunu ortaya koymuştur ${ }^{20}$.

Karasu, Karayolları Zorunlu Malî Sorumluluk Sigortası Genel Şartları'nın B.4.c. bendinde yapılan değişiklikten sonra sigortacının sigortalıya rücu hakkının doğabilmesi için kazanın münhasıran alkolün etkisiyle meydana gelmiş olması gerektiğine dair yerleşik Yargitay uygulamasının değişmesi gerektiğini belirtmiştir ${ }^{21}$. Müellif, sigortacının rücu hakkının alkolün kazaya etkisi nispetinde olması gerektiğini ifade ettikten sonra, kazada alkolün hiçbir

17 Karayolları Motorlu Araçlar Zorunlu Malî Sorumluluk Sigortası Genel Şartları'nın B.4.c bendine dair değişiklik, 14.05.2015 tarihinde Resmî Gazete'de yayımlanarak 01.06.2015 tarihinde yürürlüğe girmiştir. Söz konusu değişiklikten evvel anılan bent hükmünde, tıpk1 Kara Araçları Kasko Sigortası Genel Şartları'nın A.5. maddesinin 5.5. bendinin önceki hâlinde olduğu gibi alkollü araç kullanan sürücünün güvenli sürüş yeteneğini kaybetmiş olması şartı aranmaktaydı. Bkz. Sinan Misili, "Karayolları Motorlu Araçlar Zorunlu Malî Sorumluluk Sigortası Genel Şartları Uyarınca Sigortacının Sigorta Ettirene Rücu Davası", 2017, (133), Türkiye Barolar Birliği Dergisi, s. 620-624.

18 Misili, s. 626.

19 Misili, s. 626.

20 Misili, s. 627.

21 Rauf Karasu, Yargıtay ve Sigorta Tahkimi İtiraz Hakem Heyeti Kararları Işı̆̆ında Karayolları Zorunlu Malî Sorumluluk Sigortası (Trafik Sigortası), Yetkin Yayınları, 2016, s. 118. 
Kara Araçları Kasko Sigortası Genel Şartları ve Yürürlükte Bulunan Mevzuat...

etkisinin olmadığının ispat edilebildiği ahvalde sigortacının rücu hakkından söz edilemeyeceğini ortaya koymuştur ${ }^{22}$.

\section{Konuya İlişkin Yargıtay Kararlarının Muhtelif Açılardan Değerlendirilmesi}

\section{Genel Şart Hükümlerinin Lafzı Bakımından Değerlendirme}

Yargitay'ın konuya ilişkin yerleşik kararlarında, sürücünün alkollü olduğu esnada meydana gelen zararlara ilişkin sigortacının sorumlu olmayacağından söz edilebilmesi için, kazanın münhasıran sürücünün alkollü olmasından ileri gelmesi şartı aranmaktadır. Bu anlamda Yargıtay, sürücünün kaza esnasında tam kusurlu olması şartını aramakta ve fakat sigortacının sorumluluktan beri kılınabilmesi için sürücünün tam kusurlu olmasını da tek başına yeterli görmemektedir. Bunun yanında sürücünün kazaya sebebiyet veren tam kusurunun münhasıran alkollü olmasından ileri gelen bir kusur olması şartını da aramaktadır. Dolayısıyla sürücünün kazada tam kusurlu olması, doğrudan alkollü olmasıyla bağdaştırılabilecek bir kusur değilse, sigortacının ilgili genel şart hükümlerinden hareketle vâki zararı tazmin yükümlülüğünden kurtulamayacağı Yargitay tarafından kabul edilmektedir. Hâlbuki ilgili genel şart hükmünde kusurdan söz edilmemekte, hükmün lafzından, sürücünün zarara yol açan kaza sırasında alkollü olması halinde, kazanın oluş şekline, kusurun derecesine ve kime ait olduğuna bakılmaksızın, sigortacının tazminat ödeme borcundan kurtulacağı anlamı çıkmaktadır. Bu anlamda ilgili genel şart hükmünün lafzı ve Yargıtay tarafından kabul edilen tatbik biçimi esas itibariyle örtüşmemektedir. O hâlde söz konusu genel şart hükmünün somut uyuşmazlıklar bakımından nasıl uygulanacağına dair müstakar Yargıtay kararlarının, hükmün lafzı itibariyle isabetli olmadığı istidlâl olunmaktadır. Bu durumda Yargıtay'ın bahse konu genel şart hükmünü, lafzından çıkarılması pek mümkün olmayan şekilde uygulamasına âmil olan hukukî gerekçenin ne olabileceğinin tetkikine, farklı ölçütler nazarında devam edilmelidir.

\section{Kanuna Uygunluk Bakımından Değerlendirme}

Sigorta genel şartları, yukarıda da ifade etmiş olduğumuz üzere Kanunun emredici hükümlerine aykırı olamaz. Aksi hâlde genel şart hükümleri geçersiz addedilir ve Kanun hükümleri uygulanır ${ }^{23}$. Dolayısıyla Kanuna aykırılığ tespit edilen genel şart hükümlerinin sigorta uyuşmazlıkları bakımından

22 Karasu, s. 118-119.

23 Bozer, s 135. 
dikkate alınmaması icap etmektedir. Nitekim ilgili genel şart hükmünün 6102 sayılı Türk Ticaret Kanunu'nun "Korиyucu Hükümler" başlıklı 1452'inci maddesinde zikredilen ve aksi hiçbir şekilde yahut sigorta ettiren veya sigortalı aleyhine kararlaştırılamayacak hükümlerin kapsamı dâhilinde olduğunun tespiti halinde, ilgili genel şart hükmü yerine, konuya ilişkin Kanun hükmünün uygulanması gerekecektir ${ }^{24}$. O hâlde inceleme konusu genel şart hükmünün Yargıtay'ın müteaddit kararlarında istikrarlı biçimde lafzından farklı bir mana tahmil edilerek tefsir ve tatbik edilmesi, söz konusu genel şart hükümlerinin Kanuna aykırı olmasından mı ileri gelmektedir? Bu sualin yanıt bulabilmesi için bahse konu genel şart hükmü, ilgili Kanunların âmir mahiyet arz eden hükümleri karşısında etraflıca tetkik olunmalıdır. Bu açıklamalar doğrultusunda mesele, 6102 sayılı Türk Ticaret Kanunu'nun ve 2918 sayılı Karayolları Trafik Kanunu'nun emredici hükümleri kapsamında ele alınacaktır.

\section{a. Karayolları Trafik Kanunu Bakımından Değerlendirme}

Yukarıda da ifade etmiş olduğumuz gibi, 2918 sayılı Karayolları Trafik Kanunu'nun 48'inci maddesinin birinci fikrası hükmü uyarınca hususî araç kullanıcıları bakımından yasal sınır olan 0.50 promilin üzerinde alkollü olan kişilerin araç sürmeleri yasaktır. Söz konusu fikra hükmü, Kara Araçları Kasko Sigortası Genel Şartları'nın A.5. maddesinin 5.5. bendinde yer alan ve sürücünün alkollü olduğu sirada meydana gelen zararlardan sigortacinın sorumlu olmayacağına dair hükmün yasal dayanağını teşkil etmektedir. Nitekim yasal olarak belirlenmiş promilin üzerinde alkollü olan kişinin araç kullanması idarî para cezasını ve dahi 5237 sayılı Türk Ceza Kanunu'nun 179'uncu maddesinin üçüncü fikrası uyarınca hapis cezasını gerektiren, bu anlamda suç teşkil eden bir eylemdir. Netice itibariyle ilgili genel şart hükmünün 2918 sayılı Karayolları Trafik Kanunu'nun ilgili hükümleri çerçevesinde kanuna aykırı olduğunu söyleyebilmek kanaatimizce mümkün değildir. Bu itibarla söz konusu genel şart hükmünün kanuna uygunluğunun tetkiki, 6102 sayılı Türk Ticaret Kanunu'nun sigorta hukukuna ilişkin altıncı kitabında yer alan hükümler nazarında yapılmalıdır.

24 Emine Yazıcıoğlu, "Zarar Sigortalarında Sigorta Himayesinin Sınırlandırılması ve Davranış Yükümlülüklerinin Teminat Şartı ya da İstisna Olarak Öngörülmesi Sorunu”, Prof. Dr. Ergon A. Çetingil ve Prof. Dr. Rayegân Kender'e 50. Yı1 Birlikte Çalışma Armağanı, 2007, s. 1190 . 
Kara Araçları Kasko Sigortası Genel Şartları ve Yürürlükte Bulunan Mevzuat...

\section{b. Rizikonun Ağırlaşmasına İlişkin 6102 sayılı Türk Ticaret Kanunu'nun 1444 vd. Maddeleri Bakımından Değerlendirme}

Rizikonun ağırlaşması başlığı altında ele alınan konunun çalışmamız bakımından önem arz eden yönü, kasko sigortası sözleşmesi bakımından sigorta ettiren (yahut sigortalı) mevkiinde bulunan kimsenin alkollü araç kullanmasının rizikonun ağırlaşması olarak nitelendirilip nitelendirilemeyeceği noktasında düğümlenmektedir. Zira bu şekilde bir nitelendirme yapabilmenin mümkün olması halinde kasko sigortası genel şartlarının alkollü araç kullanımına ilişkin düzenlemesinin, Kanuna uygunluk yönünden rizikonun ağırlaşmasına müteallik 6102 sayılı Türk Ticaret Kanunu hükümleri nazarında değerlendirilmesi icap etmektedir. Nitekim 6102 sayılı Türk Ticaret Kanunu'nun 1444 vd. maddeler, aynı Kanunun “Koruyucu Hükümler” başlıklı 1452'inci maddesinin üçüncü fikrası hükmünde aksi sigorta ettiren ve sigortalı aleyhine değiştirilemeyecek hükümler arasında sayılmıştır. Bu anlamda ilgili genel şart hükmünün $1444 \mathrm{vd}$. maddeler çerçevesinde rizikonun ağırlaşmasına dair bir hüküm olduğunun tespiti halinde, ilgili genel şart hükmünün mezkûr maddelere uygun olacak şekilde yorumlanması ve hükmün ihlâline terettüp eden müeyyidenin sigorta ettiren ve sigortalı aleyhine $1444 \mathrm{vd}$. maddelerinde öngörülen müeyyideye nazaran daha ağır bir neticeye mahal vermiyor olması gerekmektedir. $\mathrm{Bu}$ başlık altında rizikonun ağırlaşmasına terettüp eden sonuçlar yerleşik Yargıtay kararları nazarında ele alınacak ve Yargıtay'ın bu husustaki istikrarlı kararlarının hukuki dayanağının TTK m. 1444 vd. olup olmadığını irdelenecektir.

Sigortacı tarafından prim miktarı tayin edilirken, sözleşmeyle teminat altına alınan rizikoların gerçekleşme ihtimalinin, sigorta sözleşmesi devam ederken esaslı bir değişikliğe uğramayacağı varsayımıyla hareket edilir. Buna karşılık tehlikenin ağırlaşması, yani rizikonun gerçekleşme ihtimalinin artması halinde sigorta sözleşmesinin değişen şartlara göre yeniden ele alınması gerekebilir ${ }^{25}$.

Rizikonun ağırlaşması iki şekilde karşımıza çıkabilir. Rizikonun gerçekleşme ihtimali, sigorta ettirenin yahut onun izniyle üçüncü bir kişinin fiili neticesinde ağırlaşabilir. Bu durum doktrinde sübjektif riziko

25 Zahit İmre, "Sigorta Hukukunda Rizikonun Ağırlaşması", 1946, 12(1), İstanbul Hukuk Mecmuas1, s. 287. 
ağırlaşmast ${ }^{26}$ yahut ihtiyarî tehlike artışı ${ }^{27}$ olarak ifade edilmektedir. 6102 sayılı Türk Ticaret Kanunu'nun 1444'üncü maddesinin birinci fikrasına göre sigorta ettiren, bu hususta sigortacının iznini almadığı müddetçe, rizikonun gerçekleşme ihtimalini artıracak davranış ve işlemlerden kaçınmakla mükelleftir. Buna rağmen sigorta ettiren yahut onun izniyle üçüncü kişiler, sigorta himayesine dâhil olan tehlikelerin ağırlaşması sonucunu doğuracak davranış veya işlemlerde bulunacak olurlarsa, sigorta ettiren durumu derhâl sigortaciya ihbar etmekle mükelleftir (TTK m. 1444/2).

Riziko, sigorta sözleşmesi devam ederken, sigorta ettirenin fillerinden sadır olmayan, onun iradesinden tümüyle bağımsız birtakım gelişmeler dolayısıyla da artmış olabilir. $\mathrm{Bu}$ durum ise doktrinde objektif riziko ağırlaşması yahut irade dişı tehlike ağırlaşması olarak ifade edilmektedir ${ }^{28}$. Riziko, sigorta sözleşmesiyle ve sigortalanan menfaatle alâkası bulunmayan üçüncü kişilerin fiillerine yahut tabii hadiselerin veya sosyolojik vakıaların cereyanına dayalı olarak ağırlaşmış ise objektif riziko ağırlaşmasından söz edilecektir. Bu hâlde sigorta ettiren, rizikonun ağırlaşmasına yol açan davranış yahut hadiseyi öğrendiği tarihten itibaren 10 günlük süre zarfında sigortaciyı bilgilendirmekle mükelleftir (TTK m. 1444/2).

6102 sayılı Türk Ticaret Kanunu'nun 1445'inci maddesinin birinci fikrası hükmüne göre, rizikonun ağırlaşmasına yol açan davranış yahut işlemlere vâkıf olan sigortac1, keyfiyeti öğrendiği tarihten itibaren bir ay içerisinde sözleşmeyi feshedebilir yahut prim farkı talep edebilir. Prim farkının on gün içinde kabul edilmemesi halinde sözleşme feshedilmiş sayılır. Buna karşılık sigortacının rizikoyu ağırlaştıran hâllere rizikonun gerçekleşmesinden sonra vâkıf olması halinde uygulanacak hükümler, sigorta ettirenin ihmâl derecesine göre değişiklik arz etmektedir. Sigorta ettirenin rizikonun ağırlaşmasında ve keyfiyeti sigortaciya ihbar etmekte ihmalkâr davrandığı tespit edilir ve bu ihmalkârlığın rizikonun gerçekleşmesine yahut ödenecek tazminat miktarının artışına müessir olduğu anlaşılırsa, sigorta ettirenin kusuru nispetinde ödenecek tazminattan indirim yapılır. Sigorta ettirenin rizikonun ağırlaşmasına dair keyfiyeti kasten ihbar etmediği hallerde, rizikoyu ağırlaştıran davranış yahut

\footnotetext{
26 Kender, s. 289; Nisim Franko, "Sigorta Akdinde Rizikonun Ağırlaşması", Ticaret Hukuku ve Yargitay Kararları Sempozyumu, 1992, 9, s. 112; Didem Algantürk Light, "Sigorta Sözleşmeleri Süresi İçerisinde Sigorta Ettirenin Yükümlülükleri”, 2012, 11(22), İstanbul Ticaret Üniversitesi Sosyal Bilimler Dergisi, 10. Yıl'a Armağan, s. 4.

27 İmre, s. 293

28 İmre, s. 295; Algantürk Light, s. 4; Franko, s. 112.
} 
Kara Araçları Kasko Sigortası Genel Şartları ve Yürürlükte Bulunan Mevzuat...

işlemler ile vâki riziko arasında illiyet bağı mevcutsa sigortacı tazminat ödeme borcundan kurtulur; aksi hâlde, sigortacı tazminatı ödenen prim ile ödenmesi gereken prim arasındaki oranı dikkate alarak öder (TTK m. 1445/5) ${ }^{29}$.

Yukarıda da ifade etmiş olduğumuz gibi, sigorta sözleşmesi devam ederken sigorta ettirenin veya onun izniyle üçüncü kişilerin sigorta himayesi kapsamında yer alan tehlikeleri ağırlaştırmaya matuf eylem ve işlemleri sübjektif riziko ağırlaşması olarak kabul edilmektedir. Bu noktada sigorta ettirenin yahut sigortalının 2918 sayılı Karayolları Trafik Kanunu'nun 48'inci maddesine mugayir olarak alkollü araç kullanması, rizikonun ağırlaşması olarak kabul edilebilir mi? Rizikonun ağırlaşması, sigorta sözleşmesiyle sağlanan teminatın kapsamında yer alan rizikonun gerçekleşme ihtimalini veya bunun neticesinde hâsıl olacak zararlı neticeyi, sözleşmenin kurulduğu anda mevcudiyeti tespit edilen olgulara nazaran artıran davranış ve işlemlerin tamamı olarak ifade edilebilir ${ }^{30}$. Bir kimsenin yasal sınırı aşan düzeyde alkollü olduğu hâlde araç kullanması, hayatın olağan akışı ve tecrübe geçmişine dayalı gerçekler dikkate alındığında, hiç kuşkusuz, trafik kazası meydana gelme ihtimalini artıran bir durumdur. Dolayısıyla sigorta ettirenin alkollü olduğu hâlde araç kullanması, sübjektif riziko ağırlaşması olduğu düşünülebilir. Acaba bu hâlde kasko genel şartlarının bu hususta sevk edilmiş olan hükümleri yerine 6102 sayılı Türk Ticaret Kanunu'nun rizikonun ağırlaşmasına müteallik hükümleri uygulanabilir mi? Bir an için bunun mümkün olabileceğini zehabına kapılsak da, rizikonun ağırlaşması ile sigorta sözleşmesiyle bahşedilen himayeden hariç tutulan, yani teminat dışı bırakılan hâller birçok yönden birbirinden ayrılmaktadır.

Öncelikle teminat dışında bırakılan haller sözleşmenin kurulduğu anda tespit edilmiş ve sigorta poliçesine yazılmıştır. Bu anlamda genel şartlar ile belirlenen teminat dışı bırakılan hâlleri de bu kapsamda değerlendirilebiliriz ${ }^{31}$. Zira genel şart hükümleri sözleşmenin kurulması anından evvel belirlenmiş olup, ilgili genel şartlar sigorta poliçesine eklenir. Dolayisıyla sigorta ettiren sözleşmenin kurulduğu anda teminat dışı bırakılan hallere de vâkıf olmaktadır. Buna karşılık rizikoyu ağırlaştıran haller sözleşmenin kuruluş anında belli olmayan, keza sigorta poliçesinde gösterilmeyen hallerdir. Bu anlamda kara araçları kasko sigortası bakımından sürücünün alkollü hâlde araç kullanması,

\footnotetext{
Söz konusu hükme dair tenkitler için bkz. Kender, s. 291-298.

Kender, s. 291.

İmre, s. 299.
} 
sigorta poliçesinin kapsamında yer alan genel şartlarda evvelce tayin edilmiş teminat dışı bir hâl olduğundan, keyfiyeti rizikonun ağırlaşması olarak kabul edebilmek kanaatimizce mümkün değildir.

Üstelik rizikonun ağırlaşması ile kastedilen, rizikonun gerçekleşme ihtimalinin sübjektif ve objektif nedenlere dayalı olarak sigorta sözleşmesinin kurulduğu andaki hâl ve şartlara göre süreklilik arz edecek şekilde artmasıdır. Diğer bir ifadeyle, rizikonun gerçekleşmesi ihtimalini yalnız geçici surette artıran hususlar rizikonun ağırlaşması kapsamında mütalâa edilemez. Söz gelimi, hayat sigortası yaptırmış bir kimsenin tatil amaçlı gittiği yurtdışı seyahatinde dağ tırmanışı aktivitesine katılmış olması, rizikonun ağırlaşması olarak nitelendirilemeyecektir. Bu durumda sigorta şirketi dă tırmanışı sırasında meydana gerçekleşen riziko dolayısıyla, rizikonun ağırlaşması hükümlerinden hareketle sorumluluktan kurtulamayacaktır; meğerki, bu mahiyetteki faaliyetler dolayısıyla gerçekleşen riziko teminat kapsamı dışında bırakılmış olsun. Buna karşılık hayatı sigortalanan kişinin, sigorta sözleşmesinin akdedilmesini müteakip bir arama kurtarma timine katılarak doğası gereği tehlike arz eden faaliyetleri meslek ittihaz etmeye başlaması, rizikonun ağırlaşması olarak kabul edilebilecektir.

Son olarak, rizikonun ağırlaşması hakkında 6102 sayılı Türk Ticaret Kanunu'nda öngörülen müeyyidenin teminat dışı bırakılan haller bakımından uygulanabilmesinin de mümkün olmadığı görülmektedir. Sigorta ettiren yahut sigortalı mevkiinde bulunan bir sürücünün alkollü araç kullanması halinde, keyfiyeti sigorta şirketine bildirmesi, hayatın olağan akışına pek de uygun kabul edilebilecek bir beklenti değildir. $\mathrm{O}$ hâlde sürücünün alkollü olduğu, sigortacının ekseriyetle rizikonun, yani trafik kazasının gerçekleşmesi sonrasında vâkıf olabileceği bir durumdur. Dolayısıyla rizikoyu ağırlaştıran olgunun rizikonun gerçekleşmesinden sonra öğrenilmesi halinde uygulanacak hüküm ve sonuçlar, alkollü araç kullanma keyfiyetine uyarlandığında, sürücünün bu durumu kasten bildirmemiş olduğu kabul edileceğinden rizikoyu ağırlaştıran hâl, yani alkollü araç kullanımı ile gerçekleşen riziko arasında illiyet bağı olup olmadığına bakılacaktır. Trafik kazası, alkollü araç kullanımından ileri gelmişse sigortacı tazminat ödemekle mükellef olmayacaktır. Bu netice yerleşik Yargıtay uygulamasında benimsenmiş olan netice ile büyük ölçüde örtüşmektedir. Ancak meydana gelen trafik kazası ile sürücünün alkollü olması arasında illiyet bağı kurulamıyorsa, başka bir deyişle, Yargıtay'ın yerleşik kararlarında da müşahede edildiği üzere trafik kazası münhasıran alkolün etkisiyle meydana gelmemişse, sigortacı, ödenen prim 
Kara Araçları Kasko Sigortası Genel Şartları ve Yürürlükte Bulunan Mevzuat...

ile ödenmesi gereken prim arasındaki oranı dikkate alarak ödeme yapacaktır. Ödenmesi gereken prim oranı, rizikoyu ağırlaştıran husus sigortacıya ihbar edilmiş olsaydı, sigortacının talep edeceği prim miktarını ifade eder. O hâlde çalışmamızın konusunu teşkil eden kara araçları kasko sigortasında sigorta ettirenin/sigortalının alkollü araç kullanması durumunda, ödenmesi gereken prim miktarı, sigortacı sigorta ettiren/sigortalı alkollü araç kullanacağını sigortacıya bildirmiş olsaydı sigortacının talep edeceği miktarı olarak mı anlaşılmalıdır? $\mathrm{Bu}$ suale müspet yanıt verilebilmesi mümkün değildir. Zira sigortacının, rizikonun gerçekleşme ihtimaline müessir olabilecek hususlar kapsamına sigorta ettirenin/sigortalının alkollü araç kullanması hâlini dâhil ederek buna göre prim miktarını artırabilmesi, 6102 sayılı Türk Ticaret Kanunu'nun "geçerli olmayan sigorta" başlıklı 1404'üncü maddesi hükmü muvacehesinde mümkün değildir. Söz konusu hüküm uyarınca, sigorta ettirenin veya sigortalının, kanunun emredici hükümlerine, ahlâka, kamu düzenine ve kişilik haklarına aykırı fiillerinin sigorta teminatı kapsamına alınabilmesi mümkün değildir. Sigorta ettirenin yahut sigortalının alkollü araç kullanması, 2918 sayı11 Karayolları Trafik Kanunu'nun 48'inci maddesinin birinci fikrası hükmüne göre Kanuna aykırı olup, promil miktarının 1.00'1 aşması halinde 5237 sayıl1 Türk Ceza Kanunu'nun 179'uncu maddesinin üçüncü fikrası hükümleri uyarınca suç teşkil etmektedir. Dolayısıyla 6102 sayılı Türk Ticaret Kanunu'nun 1445'inci maddesinin beşinci fikrası hükmünden, sigorta ettirenin veya sigortalının kanuna, kamu düzenine, ahlâka ve kişilik haklarına aykırılık teşkil eden fiillerinin, rizikoyu ağırlaştıran hususlar kapsamında mütalâa edilemeyeceği sonucu istidlâl olunmaktadır.

Netice itibariyle, ilgili genel şart hükmünün Yargıtay tarafından lafzından farklı yorumlanarak uygulanmasının, 6102 sayılı Türk Ticaret Kanunu'nun rizikonun ağırlaşması hakkında sevk edilmiş bulunan $1444 \mathrm{vd}$. maddelerine istinat ettiğini söyleyebilmek de mümkün değildir.

c. Sözleşmede Öngörülen Yükümlülüklerin İhlâline İlişkin 1449'uncu Madde Bakımından Değerlendirme

6102 say11 Türk Ticaret Kanunu'nun "Sözleşmede Öngörülen Yükümlülüklerin İhlâli” başlıklı 1449'uncu maddesi hükmünde, sigortacıya karş1 yerine getirilmesi gereken ve sözleşmeden doğan bir yükümlülüğün ihlâline bağlanan sonuçlar öngörülmüştür ${ }^{32}$. Söz konusu madde hükmünde

32 Hükmün eleştirisi için bkz. Samim Ünan, “Sözleşmesel Görevler (TTK 1449)”, 2014 (28), Ticaret Hukuku ve Yargitay Kararları Sempozyumu, s. 22-27. 
yer alan düzenlemeler, aynı Kanunun "Когиуиси Hükümler" başlıklı 1452'inci maddesinin üçüncü fikrası hükmüne göre, aksi sigorta ettiren ve sigortalı aleyhine kararlaştırılamayacak hükümler arasındadır. Dolayısıyla Kara Araçları Kasko Sigortası Genel Şartları'nın A.5 maddesinin 5.5. bendinde öngörülen hükmün 6102 say1lı Kanun'un 1449'uncu maddesi anlamında "sözleşmede öngörülen bir yükümlülük" olduğunun tespit edilmesi halinde, ilgili genel şart hükmü, mahiyeti yahut sonuçları itibariyle mezkûr 1449'uncu madde hükmüne aykırı olduğu nispette geçersiz addedilecektir. Zira sözleşmede öngörülen bir yükümlülükle ilgili 6102 sayılı Türk Ticaret Kanunu'nda düzenlenmiş olan emredici bir hüküm varsa, söz konusu yükümlülüğün ihlâline bağlanan sonuçlara ve bu sonucun doğmasında kusur ve illiyet bağının rolüne ilişkin taraf iradelerine üstünlük tanınamaz; ihlâlin sonuçlarına ilişkin ilgili Türk Ticaret Kanunu hükmünde öngörülen esaslar uygulanır ${ }^{33}$. Nitekim 6102 sayılı Türk Ticaret Kanunu'nun 1449'uncu maddesine ilişkin gerekçede, Kanunda öngörülenler dışında, uygulamada ve sigorta genel şartlarında ortaya çıkabilecek yükümlülükler olabileceğine vurgu yapılmış olması, inceleme konusu genel şart hükmünün TTK m. 1449 anlamında sözleşmede öngörülen bir yükümlülük olabileceği düşüncesini kuvvetlendirmektedir. Başka bir deyişle, ilgili genel şart hükmünün, teminat dışında bırakılan haller arasına gizlenmiş 'örtülü yahut gizli bir sözleşme yükümlülüğü’ olması pek muhtemeldir ${ }^{34}$. Nitekim TTK m. 1449 düzenlemesine ilham veren Avrupa Sigorta Sözleşmeleri Hukuku İlkeleri'nin (Principle of European Insurance Contract Law) 4:101 maddesine sevk edilmiş bulunan "Sigortacının sorumluluğu için aranan bir şart olarak tanımlanmış olsun yahut olmasin, sigorta ettirene yahut sigortaliya rizikonun gerçekleşmesinden evvel muayyen bir davranışta bulunma yahut bulunmama yükümlülüğ̈̈ getiren hükümler, sözleşme hükümleri kapsamında mütalâa olunacaktır ${ }^{35}$ " hükmü de bu mahiyetteki yükümlülüklere sözleşmede başka isimler altında yer verilmiş olabileceğine işaret etmektedir.

İnceleme konusu genel şart hükmünün TTK m. 1449 anlamında bir sözleşme yükümlülüğü olduğunun kabulü halinde, ilgili genel şart hükmüne aykırılık bakımından, sigorta ettiren/sigortalı lehine olduğu ölçüde, 6102 sayılı Kanun'un 1449'uncu madde hükmü esas alınacaktır. Bahse konu genel şart

\footnotetext{
33 Yazıcı̆̆glu, s. 1190.

34 Ünan, Sözleşmesel Görevler, s. 12-13.

$35<$ https://www.uibk.ac.at/zivilrecht/forschung/evip/restatement/sprachfassungen/peicl-en. pdf $>$ Erişim Tarihi 29.12.2021.
} 
Kara Araçları Kasko Sigortası Genel Şartları ve Yürürlükte Bulunan Mevzuat...

hükmünün mezkûr 1449'uncu madde hükmü kapsamında değerlendirilmesi, konuya ilişkin yerleşik Yargıtay uygulamasının Kanuna uygunluk yönünden tetkik edilmesi ve belki de, hukuki gerekçesinin lâyıkıyla ortaya konulabilmesi bakımından son derece önemlidir.

6102 sayılı Türk Ticaret Kanunu'nun 1449'uncu maddesinin birinci fikrası hükmüne göre, sigortacıya karşı yerine getirilmesi gereken ve sözleşmede öngörülen bir yükümlülüğün ihlâli halinde, sigortacının ihlâli gerekçe göstererek sözleşmeyi feshedebilmesi ve sözleşmeden doğan edim yükümlülüklerinden kaçınabilmesi için ihlâle ilişkin sigorta ettirene/sigortalıya atfedilebilir bir kusurun olması gerekmektedir; meğerki, 6102 sayılı Türk Ticaret Kanunu'nda yahut diğer Kanunlarda aksine bir düzenleme öngörülmüş olsun. Aynı maddenin üçüncü fikrası hükmünde ise, sigortalının sözleşmede öngörülen yükümlülüğü ihlâl etmiş olmasının rizikonun gerçekleşmesine ve sigortacının ödemesi gereken tazminat miktarının artmasına müessir olmadığ durumlarda, sigortacının sözleşmeyi feshedemeyeceği düzenlenmiştir.

Sigorta ettirenin/sigortalının alkollü araç kullandığı sırada meydana gelen zararların sigorta teminatının kapsamı dışında kalacağına ilişkin genel şart hükmünün TTK m. 1449 anlamında bir sözleşme yükümlülüğü olduğu düşünüldüğünde, sigortacının söz konusu genel şart hükmünden hareketle tazminat ödeme borcundan imtina edebilmesi için yükümlülügün ihlâlinde sigorta ettirenin/sigortalının kusurlu olması ve dahi mezkûr ihlâlin rizikonun gerçekleşmesine müessir olması gerektiği sonucu çıkmaktadır. $\mathrm{Bu}$ durumda, Yargıtay'ın konuya ilişkin yerleşik kararlarında müşahede olunan, alkollü sürücünün (tam) kusurlu olması ve kusurun münhasıran alkollü araç kullanımından kaynaklanması gerektiği yönündeki mülâhazanın 1449'uncu madde hükmüne dayandırılabileceği düşüncesi hâsıl olmaktadır.

Peki bu noktada yerleşik Yargitay uygulamasının 1449'uncu madde hükmü anlamında Kanuna uygun olduğu söylenebilir mi? İlgili genel şart hükmünde öngörüldügü ş̧ekliyle aracın yasal haddi aşan düzeyde alkollü hâlde kullanılmasının TTK m. 1449 kapsamında değerlendirilmesi gereken bir sözleşme yükümlülüğ̈̈ olduğu varsayıldığında, her şeyden evvel bu yükümlülüğün ihlâline terettüp eden sonuçların uygulanabilmesi için ihlâlin kusura dayanması gerekecektir (TTK m. 1449/1). İlgili genel şart hükmü kapsamında ihlâl, bizatihi alkollü araç kullanılması eylemidir. O hâlde alkollü araç kullanımı sigorta ettirenin yahut sigortalının kusuruna dayanmalıdır. TTK m. 1449 hükmünde kusurun derecesinden söz edilmediği için, hafif kusur halinde dahi ihlâl söz konusu olacaktır. Kaldı ki, bir sürücünün alkollü 
araç kullanması, her halükârda kast derecesinde kusuru gerekli kılacaktır. Zira alkollü hâlde araç kullanmaması gerektiğini bilen (yahut bilmesi gereken) sürücünün buna rağmen direksiyon başına geçmesi, ihlâle bilerek ve isteyerek (kasten) yol açtığı yahut (alkol düzeyinin yasal haddi aştığının tam anlamıyla bilincinde olmasa dahi) ihlâli göze alarak pervasız hareket ettiği (dolaylı kast) anlamına gelecektir. Bu anlamda alkollü araç kullanımı, TTK m. 1449 anlamında her halükârda kusura dayanan bir ihlâl olarak nitelendirilecektir. Peki ilgili genel şart hükmüne dair kusurlu ihlâl, ihlâle bağlanan sonuçların uygulanabilmesi için kâfi olacak mıdır? Anılan 1449'uncu maddenin üçüncü fikrası hükmüne göre, sigortacının sözleşmeden doğan edim yükümlülüklerinden kaçınabilmesi ve dahi sözleşmeyi feshedebilmesi için ihlâlin kusura dayanması yeterli olmayıp, ayrıca ihlâl ile gerçekleşen riziko arasında bağlantı olmalıdır. Dolayısıyla, sigortacının, alkollü araç kullanılması esnasında meydana gelen zarara ilişkin ödeme yapmaktan imtina edebilmesi için, vâki zarar ile alkollü araç kullanımı arasında illiyet bağı olmalıdır. Fakat bu hüküm kapsamında illiyet bağı ile kastedilenin ne olduğu açık değildir. İlliyet bağı ile kastedilen, konuya ilişkin yerleşik Yargıtay uygulamalarında kabul edildiği şekliyle kazanın münhasıran sürücünün alkollü olmasından ileri gelmesi midir? Bu noktada bilhassa ortak illiyetin söz konusu olduğu; mesela kazaya kişinin alkollü olmasının ve yolda buzlanma olmasının birlikte etki ettiği durumlarda, hukukî mahiyeti itibariyle TTK m. 1449 anlamında 'sözleşme yükümlülügü' olduğunu varsaydığımı genel şart hükmünün ihlâl edilmiş olduğu kabul edilecek midir? Bu hâlde riziko, biri teminat kapsamında, diğeri ise teminat kapsamında olmayan bir sebepten ileri gelmektedir. Konuya dair yerleşik Yargıtay uygulamasında benimsenmiş olan görüşe göre, sigortacının sorumluluktan kurtulabilmesi için, aynı zamanda araç sürücüsü olan sigorta ettirenin/sigortalının kazanın oluşumunda tam kusurlu olması ve kusurun münhasıran aracın alkollü hâlde kullanılmasından ileri geliyor olması gerekir. Bu itibarla münhasırlık ölçütünün benimsenmesi halinde, verdiğimiz örnek bakımından sigortacının sorumluluktan kurtulabilmesi mümkün olmayacaktır. Esasen TTK m. 1449 hükmünden, illiyet bağının kurulabilmesi için Yargıtay tarafından benimsenmiş olan ve rizikonun münhasıran sözleşme yükümlülüğünün ihlâli dolayısıyla meydana gelmiş olması gerektiğine dair katı yorum tarzını haklı gösterecek hukukî bir sebebin mevcut olmadığını düşünüyoruz. Kanaatimizce bu hususta İngiliz sigorta hukuku uygulamasinda içtihatlar yoluyla benimsenmiş olan 'en yakın sebep (proximate cause)' 
Kara Araçları Kasko Sigortası Genel Şartları ve Yürürlükte Bulunan Mevzuat...

teorisinin uygulanmas1 yerinde olabilir ${ }^{36}$. Buna göre, muayyen bir hadiseyle gerçekleşen riziko arasında illiyet bağı kurulabilmesi için, sözkonusu hadisenin rizikonun gerçekleşmesinde birinci derecede rol oynaması, yani rizikoya yol açan aslî sebebinin o hadise olması gerekmektedir. Buna karşılık zarara yol açan sebeplerden biri teminat kapsamında, diğeri teminat kapsamı dışında ise bunlar arasından zararın gerçekleşmesinde diğerine nazaran baskın olan sebep (predominant cause) tespit edilir. Sigortac1 ancak baskın sebep teminat kapsamındaysa sorumlu tutulabilir, aksi hâlde sigortacının sorumluluğundan söz edilemez. Ancak rizikoya yol açan birden ziyade sebebin rizikoya olan etkisi aynı ölçüdeyse, diğer bir ifadeyle, sebepler arasında baskın-baskın olmayan sebep ayrımı yapılamıyorsa, bu durumda değerlendirme, teminat kapsamı dışında bırakılan haller göz önünde bulundurularak yapılır. Öyle ki, rizikoya yol açan sebeplerden biri teminat kapsamında olmakla birlikte, diğeri açıkça teminat kapsamı dışında bırakılmışsa sigortacı gerçekleşen zarardan sorumlu olmayacaktır. Bununla birlikte, rizikoya yol açan sebeplerden birinin teminat kapsamında olduğu poliçede belirtilmiş olmasına rağmen, diğerinin teminat kapsamı dışında bırakıldığına dair açık bir kararlaştırma yoksa, sigortacı zararı tazmin etmekle mükellef olacaktır ${ }^{37}$. Bizim de katıldığımız bu teoriden hareketle, sürücünün alkollü olduğu sırada meydana gelen bir kaza bakımından, kazanın yegâne sebebi sürücünün alkollü hâlde araç kullanması değilse de, en yakın sebep (proximate cause) yahut baskın sebep (predominant cause) sürücünün alkollü olması ise, TTK m. 1449 anlamında riziko ile ihlâl arasında illiyet bağı olduğu kabul edilmeli ve sigortacı gerçekleşen zarar dolayısiyla sorumlu tutulmamalıdır.

$\mathrm{Bu}$ açıklamalar 1şığında, inceleme konumuz olan Kara Araçları Kasko Sigortası Genel Şartları'nın A.5. maddesinin 5.5. bendi hükmünün TTK m. 1449 anlamında bir 'sözleşme yükümlülüğü' kabul edilse dahi yerleşik Yargıtay uygulamasına iştirak edebilmek, kanaatimizce mümkün değildir. Zira yukarıda da ifade etmiş olduğumuz gibi, anılan 1449'uncu madde hükmünden, sigortalının rizikonun gerçekleşmesinde tam kusurlu olması gerektiği ve ihlâl ile riziko arasındaki illiyet bağından anlaşılması gerekenin 'münhasırlık ölçütü” olduğu sonucuna ulaşabilmek pek mümkün gözükmemektedir.

36 Doktrinde Ünan, bu gibi hallerde "orantısal ödeme" yönteminin uygulanması gerektiğini, daha açık bir anlatımla, sigortalının sigorta himayesinden yararlanma hakkını yalnız alkolün etkisi oranında kaybetmesi gerektiğini savunmaktadır. Bkz. Ünan, Yargıtay Kararı Değerlendirmesi, s. 129.

37 Ayrıntılı bilgi için bkz. Özlem Gürses, Marine Insurance Law, Second Edition, Routledge 2017, s. 160-163. 


\section{Korunmaya Değer Hukuki Menfaat Prensibi Yönünden Değerlendirme}

Kara Araçları Kasko Sigortası Genel Şartları'nın A.5. maddesinin alkollü araç kullanımına ilişkin 5.5. bendi hükmünün tarafların korunmaya değer hukuki menfaati bakımından yorumlanması, belki de Yargitay'ın konuya dair yerleşik uygulamalarının hukuki bir zemine oturtulmasını sağlayabilecektir.

Yargıtay, Kara Araçları Kasko Sigortası Genel Şartları'nın alkollü araç kullanımına ilişkin hükmünü yorumlarken, hiç kuşku yok ki sigorta ettirenin/ sigortalının korunmaya değer hukukî menfaatlerini öncelemektedir. Nitekim yerleşik Yargıtay uygulamasında sigorta ettirenin/sigortalının kaza esnasında yasal haddi aşan düzeyde alkollü olması, sigortacının tazminat ödeme borcundan kurtulması için yeterli görülmeyerek, kazanın münhasıran alkolün etkisiyle meydana gelmiş olması aranmaktadır. Dolayısıyla alkollü olduğu hâlde araç kullanan sigortalının kazanın meydana gelmesinde tam kusurlu olması ve hatta tam kusurun büyük oranda alkolden ileri gelmesi, sigortalının vâki zarara ilişkin sigorta tazminatı hakkından mahrum kalması için yeterli ve haklı bir gerekçe olarak kabul edilmemektedir. Yargıtay, sigortalının sigorta tazminatından mahrum kalabilmesi için tam kusurlu olmasının yanı sıra, kendisine atfedilen kusurun münhasıran alkolden ileri gelmesi gerektiğini kabul ediyor. O hâlde Yargitay'ın kazanın meydana gelmesinde tam kusurlu olmayan veya tam kusurlu olmasına rağmen tam kusuru münhasıran alkollü olmasıyla ilişkilendirilemeyen sigortalıların, sigortacı karşısında ve açık genel şart hükümlerine rağmen korunmaya değer hukuki menfaatlerinin bulunduğunu kabul etmekte olduğu tereddüde mahal vermeyecek ölçüde açıktır. Yargıtay'ın bu yöndeki tutumu kanaatimizce münakaşayı muciptir.

Öncelikle şunu ifade etmeliyiz ki, yasal sınırı aşan düzeyde alkollü olduğu hâlde araç kullanan kişi, her şeyden önce Kanuna aykırı hareket etmekte ve trafik güvenliğini tehlikeye sokma suçunu işlemektedir. Filhakika, 2918 sayılı Karayolları Trafik Kanunu'nun 48'inci maddesinin birinci fikrası hükmü uyarınca hususî araç sürücüleri bakımından 0.50 promilin, diğer araç sürücüleri bakımından ise 0.20 promilin üzerinde alkollü sürücülerin karayolunda araç kullanması yasak olup, 1.00 promilin üzerinde alkollü olduğu hâlde araç kullanan kişiler ise TCK m. 179/3 gereğince trafik güvenliğini tehlikeye sokma suçunun faili haline gelmektedirler. Kanunda açıkça yasaklanmış bir eylemi gerçekleştiren, üstelik çoğu zaman suç işleyen kişilerin sigortacı karşısında korunmaya değer menfaatleri olduğunu söyleyebilmek kanaatimizce son derece güçtür. Üstelik sürücülerin alkollü 
Kara Araçları Kasko Sigortası Genel Şartları ve Yürürlükte Bulunan Mevzuat...

oldukları sırada araç kullanmalarını yasaklayan Kanun hükümleri, sürücüleri değil esasen üçüncü kişileri korumak amacıyla sevk edilmiştir. Dolayısıyla alkollü olmalarına rağmen araç kullanan kişileri, başkalarının can ve mal güvenliklerini tehlikeye atan kişiler kapsamında değerlendirmek icap eder. Nitekim tüm dünyada olduğu gibi Türkiye'de alkollü araç kullanan kişilerin yol açtıkları kazalar çok sayıda can kaybına, sakatlığa ve mal kayıplarına yol açmaktadır $^{38}$. Bu durumda, Kanunun açık hükümlerini ihlâl eden ve kendileri dışında üçüncü kişilerin hayatlarını da tehlikeye atan alkollü sürücülerin, ilgili genel şart hükmünü lafzından ve Kanunun emredici hükümlerinden öngörülenden tamamen farklı yorumlamayı gerektirecek ölçüde korunmaya değer menfaat sahipleri oldukları düşünülebilir mi? Bu noktada benzer bir kazayı hiç alkol almamış sürücülerin de yapabileceği, dolayısıyla sürücünün alkol almış olmasının tek başına üçüncü kişilerin can ve mal güvenliklerini tehlikeye attıkları mülâhazasının somut olay gerçekliğiyle bağdaşmadığı ileri sürülebilir. Ne var ki, alkol almış bir sürücünün kaza yapma olasılığının alkol almamış aynı deneyim ve becerideki bir başka sürücüye nazaran daha yüksek olduğu uzun izahatı gereksiz kılacak ölçüde açıktır. Dolayısıyla kaza sırasında alkollü olan bir sürücüyle hiç alkol almamış olan sürücüyü aynı şekilde değerlendirmek yerinde olmayacaktır ${ }^{39}$.

Öyle zannediyoruz ki, Yargitay bu noktada, çoğu zaman tüketici sıfatını haiz olmasından hareketle sigorta ettirenin sözleşmenin zayıf tarafı olduğunu düşünerek ilgili genel şart hükmünü sigorta ettiren lehine yorumlamanın zayıf taraflı sözleşmelerin bir gereği olduğu mülâhazasına dayanmaktadır. Sigorta sözleşmesinin, sigorta ettirenin tüketici olduğu ahvâlde zayıf taraflı sözleşmelerden olduğu mülâhazasına katılmakla beraber, sözleşmenin ve sözleşmenin bir parçası olan genel şartların her durumda sigorta ettiren lehine yorumlanmasının, her ne kadar temel saikanın hakkaniyetin tesisi olduğuna şüphe yoksa da, bazen hakkaniyete uygun olmayan sonuçlara yol açtığ1 müşahede olunmaktadır. Nitekim Yargıtay'ın alkollü araç kullanan sürücüler lehine tesis ettiği yerleşik uygulaması, aslında yasalara uygun hareket eden diğer poliçe sahipleri aleyhine bir sonuç ortaya koymaktadır. Zira sigortacıların, ilgili genel şart hükmünün hilafına olacak şekilde alkollü araç kullanımı sırasında meydana gelen kazalar dolayısıyla tazminat ödemek zorunda kalması, her bir poliçe başına düşen giderlerinin artması sonucunu doğurmaktadır. Bu durum ister istemez sigorta prim miktarları tayin edilirken

38 Ünan, Yargitay Kararı Değerlendirmesi, s. 123, 125.

39 Bkz. Ünan, Yargıtay Kararı Değerlendirmesi, s. 132. 
de dikkate alınmakta ve her bir sigortalının ödeyeceği yıllık prim miktarlarında artış yaşanmasına sebebiyet vermektedir ${ }^{40}$. Bu itibarla yerleşik Yargitay uygulaması, esasen Kanuna aykırı hareket eden sigortalıları korumak adına diğer sigortalıların katlanmak zorunda kaldıkları malî külfetin artmasına yol açmaktadır.

Yargıtay'ın ilgili genel şart hükmünü lafzından farklı yorumlayarak, gerçekleşen riziko, yani trafik kazası ile sürücünün alkollü olması arasında münhasır etki şeklinde tecessüm eden illiyet bağı şartını aramasının hükmün sevk amacıyla da bağdaşmadığı kanaatindeyiz. Zira hükmün amac1, teminat dışında bırakılan bir hâli ortaya koymanın yanında, sürücülerin alkollü oldukları hâlde araç kullanmalarının önüne geçmektedir. Filhakika, alkollü hâlde araç kullandıkları sırada araçta meydana gelen zararın sigorta şirketi tarafından karşılanmaması, araç sürücüleri bakımından alkollü araç kullanmaya ilişkin son derece caydırıcı bir hak mahrumiyeti olarak karşımıza çıkmaktadır. Buna karşılık bu husustaki yerleşik Yargıtay uygulamasının bu noktadaki caydırıcılığı zayıflattığı, daha da ötesinde alkollü hâlde araç kullanımına cesaret verici bir etki yarattığı kanaatindeyiz.

\section{4. "Hangi Sürücü?" Sorusu Çerçevesinde Yerleşik Yargitay Kararlarında Kabul Edilen "Münhasırlık" Ölçütünün Eleştirisi}

Yerleşik Yargıtay kararlarında, yukarıda da ifade etmiş olduğumuz gibi, kaza münhasıran alkolün etkisiyle meydana gelmedikçe sigortacının tazminat ödeme borcundan kurtulmayacağı kabul edilmektedir. Buna göre, sigorta konusu araçta meydana gelen kazanın yegâne sebebi, sürücünün yasal haddi aşan düzeyde alkollü olması değilse, sigortacının zarara ilişkin sorumluluğuna halel gelmektedir. $\mathrm{Bu}$ anlamda kazanın oluşumunda, sürücünün alkollü olması dışında başka bir sebebin de etkili olmuş olabileceği yönünde bulgular varsa, ilgili genel şart hükmü uygulanmamakta, sigortacı vâki zararı ödemekle mükellef kılınmaktadır. Yargıtay, kazanın münhasıran alkolün etkisinde meydana gelmiş olup olmadığının tespiti bakımından uzman görüşüne müracaat edilmesi ve uzmanlar arasında sürücünün güvenli sürüş yeteneğinin kaybolmuş olup olmadığını, somut olayın özelliklerini dikkate alarak tespit edebilecek bir nörologla birlikte kazanın oluş biçimini tetkik edecek bir trafik uzmanının olması gerektiğini salık vermektedir. Bu noktada akıllara şöyle bir soru gelmektedir. Kazanın münhasıran alkolün etkisiyle meydana geldiğini

40 Ayten ÇETIN / Serdar ALPAY, "Sigorta Hileleri, Türk Sigorta Sektörüne Yönelik Bir Degerlendirme", 2019, 2, Management and Political Science Review, s. 8. 
Kara Araçları Kasko Sigortası Genel Şartları ve Yürürlükte Bulunan Mevzuat...

tespit ederken esas alınacak sürücü kıstası nedir? Başka bir deyişle, söz konusu uzman raporu, hangi sürücü göz önünde bulundurularak tanzim olunacaktır. Zira tecrübesiz ve günlük işlerinde nispeten dikkatsiz bir sürücünün alkolün etkisi altında olmadan yapabileceği bir kazayı, çok tecrübeli ve dikkatli bir sürücü ancak almış olduğu alkolün yarattığ1 etkiyle yapabilir. Söz gelimi, normal şartlar altında otoyolda araç kullanırken önüne çıkan vahşi bir hayvanı fark ettiği anda gereken manevrayı, aracın yoldan çıkmasını engelleyecek şekilde yaparak kazayı atlatabilecek deneyimde bir sürücü, alkolün reflekslerinde ve manevra hızında yarattığı menfî etki dolayısıyla saniyelik de olsa geç reaksiyon göstermesi yüzünden kaza yapabilir. Buna karşılık deneyimsiz ve belki de kişiliği itibariyle çabucak paniğe kapılmaya müsait bir sürücü, önüne çıkan vahşi hayvanı gördüğünde, hiç alkol almamış, aksine son derece zinde olmasına rağmen, gerekli reaksiyonu göstermede gecikmeye düşerek kazanın gerçekleşmesine mani olamayabilir. O hâlde münhasırlık ölçütünün her somut olayın şartlarında bu derece kapsamlı bir analiz çerçevesinde mi değerlendirmesi gerekecektir? Keza normal şartlar altında son derece temkinli ve deneyimli olan sürücünün bir anlık dikkatsizliği sonucunda gerçekleştirdiği kazaya, evden çıkmadan evvel içmiş olduğu iki duble viskinin mi, yoksa bir önceki gece eşiyle yaşamış olduğu münakaşanın yarattığı hayal kırıklığı ve teessür neticesinde oluşan dalgınlığın mı yol açtığını tam olarak tespit edebilmek gerçekten mümkün olacak mıdır? Gerçekleşen her kaza bakımından, sürücünün deneyim durumunu ve içinde bulunduğu koşulların özellik arz eden yönlerini bu denli etraflıca analiz edilebileceğini, dolayısıyla münhasırlık ölçütünün tespiti bakımından müracaat edilen uzman görüşünün kazanın tümüyle alkolün etkisiyle gerçekleşmiş olup olmadığına dair kesin cevabı tam manasıyla verebileceğini söyleyebilmek, kanaatimizce pek mümkün değildir. Nitekim uzman raporları kesin bir sonuç ortaya koymaktan kaçınan, daha ziyade kazanın alkol dışında başka bir sebebin de etkisiyle meydana gelmiş olabileceğine dair ihtimallere işaret eden muğlâk ifadeler içermektedir. Yargıtay'ın ise bu muğlâk ifadelerden hareketle, bir bakıma ceza yargılaması bakımından geçerli olan "şüpheden sanık yararlanır" ilkesini bu mahiyetteki uyuşmazlıklara teşmil ederek sigortalı/sigorta ettiren lehine bir tutum sergilediği müşahede olunmaktadır. Bütün bu izahat neticesinde, yasal haddi aşan düzeyde alkollü olduğu hâlde araç kullanan kişilerin sebep olduğu kazalar bakımından, kazanın münhasıran alkolün etkisiyle mi gerçekleşmiş olduğunun tespitine dair çabaların bize bu hususta kesin bir cevap verebileceği düşüncesinde değiliz. Bu itibarla, kandaki alkol promil oranı yasal haddi aşan sürücülerin yol açtığı kazalar bakımından, kural olarak, kazanın oluşumuna 
sebep veren başka etkenlerin de olabileceği ihtimali göz ardı edilerek, ilgili genel şart hükmünün uygulanması ve vâki zararın teminatın kapsamı dışında tutulması gerektiğini kanaatindeyiz. Aksini kabul, sigortacıları kazanın münhasıran alkolün etkisiyle gerçekleşmiş olduğuna dair ispatının çok güç, hatta neredeyse imkânsız olduğu bir senaryo içerisinde hak aramaya mecbur etmek, deyim yerindeyse çoğu zaman peşinen mesul kılmak anlamına gelecektir. Bu yönde bir neticenin ortaya çıkmasına yol açan yerleşik Yargıtay uygulamasının sigorta sözleşmesinin esasını teşkil eden riziko-prim dengesine de zarar verdiği muhakkaktır.

Nitekim doktrine Ünan da Yargıtay'ın münhasırlık ölçütüne ilişkin yerleşik uygulamasını gözden geçirmesi gerektiği uyarısında bulunmaktadır ${ }^{41}$.

\section{Görüşümüz}

Kara Araçları Kasko Sigortası Genel Şartları'nın A.5. maddesinin 5.5. bendinde yer alan hükmün, yukarıda tafsilatlı biçimde izah ettiğimiz gerekçeler dolayısıyla rizikonun gerçekleşmesinde kusur yahut rizikonun ağırlaşması başlığı altında değerlendirilip yorumlanması gereken bir hüküm olmadığı kanaatindeyiz. Keza söz konusu hükmün 6102 sayılı Türk Ticaret Kanunu'nun 1449'uncu maddesi anlamında bir sözleşme yükümlülüğ̈̈ olduğunu da düşünmüyoruz. Zira sözleşmesel yükümlülükler, sigortac1 tarafından sağlanan sigorta himayesinin her iki taraf bakımından adil kabul edilebilmesi ve sigortacılık sektörünün devamı için elzem olan riziko/prim dengesinin sarsılmaması için sigorta ettirene ve/veya sigortalıya tahmil olunan menfî yahut müspet yükümlülüklerdir. Sigorta ettirenin/sigortalının sözleşmesel yükümlülüklere riayet etmesi, sözleşmenin kuruluş aşamasında gözetilen riziko/prim dengesinin sözleşme süresince devamını sağlayacaktır. Söz gelimi, sigortalıya hırsızlık sigortasıyla teminat altına alınan konutuna alarm taktırmasına ilişkin genel şart hükmü bu kapsamda mütalâa edilebilir ${ }^{42}$. Teminat dışı kalan haller ise sigorta ettirenin/sigortalının harfiyen riayet etmeyi açık yahut zımnî biçimde taahhüt ettiği hâllerdir. Teminat şartı olarak da nitelendirilebileceğimiz bu mahiyetteki taahhütler, yerine getirilmemesi halinde rizikonun gerçekleşmesine doğrudan sebebiyet verebilecek hâllere ilişkindir ${ }^{43}$. Dolayısıyla bu hâllerin teminat kapsamına alınması, bir yerde, sigorta sözleşmesinin temelini oluşturan riziko/prim dengesini tümüyle alt

41 Ünan, Yargıtay Kararı Değerlendirmesi, s. 133.

42 Yazıcıŏlu, s. 1193.

43 Yazıcıŏglu, s. 1193. 
Kara Araçları Kasko Sigortası Genel Şartları ve Yürürlükte Bulunan Mevzuat...

üst edebilecek sonuçları da beraberinde getirecektir. Nitekim teminat kapsamı dışında bırakılan hâller, ekseriyetle sigortacının hiçbir hâl ve şartta sözleşmeyle teminat altına almak isteyeceği hallerdir. Söz gelimi, sigortacılar, yüksek prim miktarları karş11ığında dâhi olsa, sürücünün uyuşturucu madde yahut alkolün etkisi altında olduğu veya sigorta konusu aracın ehliyet sahibi olmayan kimselerce kullandığı sırada meydana gelebilecek zararları teminat altına almak istemez. O hâlde bu mahiyetteki hükümlerin TTK m. 1449 anlamında sözleşmesel yükümlülüklerden tefrik edilmesi icap etmektedir. Şunu da ifade etmek gerekir ki, sözleşmesel yükümlülüklerin kusurun her derecesiyle ihmal edilebilmesine karşın, teminat şartı olarak nitelendirilen taahhütler, doğası gereği ancak doğrudan yahut dolaylı kast ile ihlâl edilebilecektir. Söz gelimi bir kimsenin binek aracıyla illegal yarışlara katılması, alkol yahut uyuşturucu madde etkisi altında veya ehliyetsiz olarak araç kullanması ihmâl sonucu ortaya çıkabilecek bir ihlâl olamaz. Buna karşılık hırsızlık rizikosuna karşı sigortalanan konutta alarmın yahut güvenlik kamerasının olmaması, söz gelimi bozulan bir kameranın yahut alarmın yenisinin takılmasında gösterilen ihmâlden ileri gelmiş olabilir.

Bu noktada ilgili genel şart hükmünün 6102 sayılı Türk Ticaret Kanunu'nun "geçerli olmayan sigorta” başlıklı 1404'üncü maddesi hükmü kapsamında da değerlendirilmelidir. Söz konusu hüküm uyarınca, "Sigorta ettirenin veya sigortalının Kanunun emredici hükümlerine, ahlâka, kamu düzenine, kişilik haklarına aykırı bir fiilinde doğabilecek bir zararını teminat altına almak amactyla sigorta yapılamaz." $\mathrm{O}$ halde bir kimsenin yasal haddi aşan düzeyde alkollü araç kullanması sırasında meydana gelen zararlar teminat kapsamına alınabilir $\mathrm{mi}^{44}$ ? $\mathrm{Bu}$ anlamda ilgili genel şart hükmünü ve dolayısıyla yerleşik Yargıtay uygulamasını mezkûr madde hükmü nazarında mı değerlendirmek icap eder? Ne var ki, ilgili genel şart hükmünün teminat dışında bıraktığı hallerin kapsamı, bahse konu Kanun maddesine nazaran daha geniştir. Zira anılan madde hükmü uyarınca sigorta ettirenin/sigortalının alkollü araç kullanması dolayısıyla yol açtığı zararlar teminat kapsamında değerlendirilmezken, ilgili genel şart hükmünde alkollü araç kullanılması sırasında meydana gelen zarar teminat kapsamı dışında bırakılmıştır. $\mathrm{Bu}$ anlamda 6102 sayılı Türk Ticaret Kanunu'nun 1404'üncü maddesi, sigortanın geçersiz addedilebilmesi bakımından kanuna, kamu düzenine yahut ahlâka aykırı davranış ile gerçekleşen riziko arasında illiyet bağı şartı ararken, ilgili genel şart hükmü, lafzı itibariyle alkollü araç kullanma ile gerçekleşen riziko

44 Konuya ilişkin tartışmalar için bkz. Ünan, Yargıtay Kararı Değerlendirmesi, s. 125-127. 
arasında illiyet bağı şartı aramamakta; kazanın alkollü araç kullanılması sırasında meydana gelmesini yeterli kabul etmektedir. Dolayısıyla ilgili genel şart hükmünün TTK m. 1404'e nazaran teminat altına alınabilecek hususların kapsamını daralttı̆̆ görülmektedir. Peki bu mümkün müdür?

İlgili genel şart hükmü, kanaatimizce, 6102 sayılı Türk Ticaret Kanunu'nun "sigortanın kapsamı" başl1klı 1409'uncu madde hükmü çerçevesinde ele alınmalıdır. Bahse konu maddenin birinci fikrası hükmü uyarınca, sigortacı, sözleşmede öngörülen ve riziko kapsamında mütalâa olunan hadiselerin gerçekleşmesi dolayısıyla ortaya çıkan zararı yahut poliçede gösterilen bedeli ödemekle mükelleftir. O hâlde zarar sigortaları bakımından sigortacı, sigortalanan menfaate yönelik her türlü zararı karşılamakla mükellef olmayıp, yalnız sözleşmede belirtilen rizikoların yol açtığı zararı karşılamayı üstlenmektedir ${ }^{45} . \mathrm{Bu}$ anlamda rizikoların sözleşmeye tayin edilebilmesi mümkün olduğu gibi, sigortalanan menfaate yönelik bazı tehlikelerin sigorta himayesinden hariç tutulabilmesi de mümkündür. $\mathrm{Bu}$ gibi haller genellikle sigorta poliçelerine ekli olan ve sözleşmenin bir parçası olarak kabul edilen genel şartlarda "teminat dışı bırakılan hâller" başlığı altında gösterilmektedir. Nitekim sigorta ettirenin/sigortalının alkollü araç kullandığı sırada meydana gelen trafik kazaları dolayısıyla ortaya çıkan zararların teminat kapsamı dışında bırakılacağı, Kara Araçları Kasko Sigortası Genel Şartları'nın “teminat dışı bırakılan hâller" başlığı altında yer almaktadır.

Teminat dışı bırakılan hâl, sigortalanan menfaate yönelik zararın sebebi oluşturan, yani rizikoyla arasında illiyet bağı bulunan bir hadise olabileceği gibi; doğrudan doğruya rizikoya yol açmayan ve fakat sigorta himayesini askıya alınması neticesini doğuran bir hadise yahut gelişme de olabilir. Bir hususun teminat kapsamı dışında bırakılabilmesi için, onun muhakkak rizikoyu meydana getirecek hadiselerden birisi olarak tavsif edilmesi şart değildir. Söz gelimi, Kara Araçları Sigorta Genel Şartları'nın A.5 maddesinin 5.8. bendine göre "aracın ruhsatında belirtilen taşıma haddinden fazla yük ve yolcu taşıması sırasında meydana gelen ve münhasıran aracın istiap haddinin aşılmasından kaynaklanan zararlar" teminat kapsamı dışında bırakılmış olup, bu bent hükmüne dayalı olarak sigortacının tazminat ödeme borcundan imtina edebilmesi için, zararın araçta haddinden fazla yük taşınması esnasında

45 Böylelikle 6762 sayılı mülga Türk Ticaret Kanunu döneminde benimsenmiş olan umumîlik (ALL RISKS) prensibinden vazgeçilmiştir. Bkz. Mertol Can, "Gözden Geçirilmeye Muhtaç Hükümler Var Mı?” Sorusu Çerçevesinde 6102 Sayılı Türk Ticaret Kanunu Hükümlerine Göre Sigorta Sözleşmesinin Tabi Olduğu Hukukî Esaslar, İmaj Yayınevi, 2011, s. 50. 
Kara Araçları Kasko Sigortası Genel Şartları ve Yürürlükte Bulunan Mevzuat...

meydana gelmesi yeterli olmayıp, söz konusu zararın münhasıran taşıma kapasitesinin aşı1mış olmasından ileri gelen bir zarar olması şarttır. Diğer bir ifadeyle, sigorta himayesinden hariç bırakılan bu hâl bakımından gerçekleşen riziko ile taşıma kapasitesinin aşılması arasında illiyet bağı olmalı; zarar münhasıran taşıma kapasitesinin aşılmasından kaynaklanmış olmalıdır. Buna karşı1ık Kara Araçları Kasko Sigortası Genel Şartları'nın A.4. maddesinin 4.1. bendine göre, kasko sigortasıyla sağlanan teminatın kapsamı, aksine mukavele yapılmadıkça, yalnız Türkiye sınırları içerisinde geçerlidir. O hâlde aracın Türkiye sınırları dışında olduğu süre zarfında meydana gelen zararlar dolayısıyla, sigorta ettirenin/sigortalının kusurlu olup olmadığına ve dahi gerçekleşen zararın Türkiye sınırları dışına çıkılmış olmasından ileri gelen bir zarar olduğuna ispata gerek kalmaksızın, sigortacının tazminat ödeme borcundan söz edilemeyecektir. Burada 6102 sayılı Türk Ticaret Kanunu'nun 1409'uncu maddesi uyarınca sigortaciya tahmil olunan ispat yükü, zararın Türkiye sınırları dışında meydana gelmiş olduğunun ispatlanması meselesine hasredilmiş bir yükümlülük olarak kabul edilecektir. Bu hususta bir diğer örnek olarak Hayat Sigorta Genel Şartları'nın A.3. maddesinin 3.1. bendini verebiliriz. Bahse konu hüküm uyarınca hayatı sigortalanan kişi, yolcu sıfatı taşımaksızın bulunduğu hava nakil aracında ve havada yapılan yolculuk esnasında hayatını kaybedecek olursa, sigorta şirketi sözleşmede kararlaştırılan bedeli ödemekle mükellefi değildir. Bu hâlde de sigortalının ölümünün hangi sebeple meydana geldiği, ölüme yol açan hadise bakımından sigortalının kusurunun bulunup bulunmadığ önem arz etmemektedir.

Sigorta teminatının kapsamı dışında bırakılan ve gerçekleşen rizikoyla aralarında illiyet bağı aranmayan hâlleri, sigorta himayesinin askıya alındığ 1 hâller olarak da ifade edebilmek pekâlâ mümkündür. Teminat dışı bırakılan haller, bilhassa zararın nasıl gerçekleştiğinin sigortacı tarafından ispatının çok zor yahut imkânsız olduğu hallerde, sözleşmenin sigortalı tarafından suiistimalini önlemek ve menfaatler dengesinin sigortacı aleyhine bozulmasına mani olmak için kabul edilmişlerdir ${ }^{46}$.

Nitekim sigortacının, Kanunun emredici hükümlerine aykırı olmaması koşuluyla, lüzum gördüğü hususları teminat kapsamı dışında bırakabileceği kabul edilmektedir ${ }^{47}$. Ancak teminat kapsamı dışında bırakılacak hususlar açıkça belirtilmeli ve söz konusu sınırlamalar kişinin temel hak ve

46 Rob Merkin / Özlem Gürses, "The Insurance Act: 2015, Rebalancing the Interests of Insurer and Assured", 2015, 78 (6), The Modern Law Review, s. 1017.

47 İmre, s. 299. 
özgürlüklerini kısıtlayıcı mahiyette olmamalıdır ${ }^{48}$. Söz gelimi sözleşmeyle sağlanan sigorta himayesinin geçerliliği, sigorta ettirenin/sigortalının seyahat özgürlüğünü yahut çalışma özgürlüğünü esaslı surette kısıtlayacak birtakım şartlara bağlanamaz.

$\mathrm{Bu}$ açıklamalar karşısında, Kanunen yasaklanmış olan alkollü araç kullanımı sırasında meydana gelen zararların sigorta teminatının kapsamı dışında oldukları kabul edilerek bu mahiyetteki zararlar bakımından, gerçekleşen zarar ile alkollü araç kullanma arasında illiyet bağı olup olmadığına bakılmaksızın, sigortacının tazminat ödeme borcunun olmadığının kabul edilmesi gerektiği kanısındayız. Nitekim bu yönde bir kabul, yukarıda da ifade etmiş olduğumuz gibi, 6102 sayılı Türk Ticaret Kanunu'nun sigorta hukukuna müteallik amir hükümlerine aykırılık teşkil etmediği gibi, alkollü araç kullanımını yasaklayan 2918 sayılı Karayolları Trafik Kanunu ve 5237 sayılı Türk Ceza Kanunu hükümleriyle örtüşmektedir.

VI. Bir Çözüm Önerisi Olarak 2015 tarihli İngiliz Sigorta Kanunu (Insurance Act 2015) Hükümlerinin Uygulanması (Kurtuluş Kantț)

Kara Araçları Kasko Sigortası Genel Şartları'nın A.5. maddesinin 5.5. bendine yönelik eleştiriler, yasal haddi aşan düzeyde alkollü araç kullanan kişilerin güvenli sürüş yeteneklerini kaybettiklerinin her zaman için söylenemeyeceği, bu yüzden kazanın tümüyle dış etkenlerin tesiriyle yahut üçüncü kişinin kusuruyla gerçekleştiği ahvalde, sigorta şirketinin sırf sürücünün alkollü olmasını gerekçe göstererek ödeme yapmaktan imtina etmesinin hakkaniyete aykırı bir sonuç ortaya çıkaracağı noktasında toplanmaktadir.

Bu eleştirilere iştirak ettiğimizi söyleyemeyiz. Zira yukarıda da ifade etmiş olduğumuz gibi, ilgili genel şart hükmünün nihaî amac1, üçüncü kişilerin can ve mal güvenliklerini koruyabilmek adına sürücülerin alkollü oldukları hâlde direksiyon başına geçmelerini önlemektir. Bu anlamda söz konusu hükmün, alkollü araç kullanan sürücüler bakımından, caydırıcılık unsurunu da ihtiva eden medenî bir ceza olduğu kanaatindeyiz. Üstelik mezkûr hükmün sigorta sözleşmesiyle sağlanan teminatı, alkollü araç kullanılan süre için askıya alan bir işlevi haiz olduğu uzun izahatı gereksiz kılacak ölçüde açıktır. Bu anlamda alkollü araç kullanan kişinin, o sırada meydana gelen zararı -zararın meydana gelmesinde tümüyle kusursuz olsa dahi- sigortacıdan talep edemiyor olmas1,

48 İmre, s. 299. 
Kara Araçları Kasko Sigortası Genel Şartları ve Yürürlükte Bulunan Mevzuat...

hükmün ulaşmak istediği gayeyle örtüşmektedir. Ancak Yargitay, söz konusu hükmü ve ortaya çıkardığı sonuçları, hakkaniyetle bağdaşmayacak ölçüde ağır bulduğundan olsa gerek, yerleşik uygulamasını hükmün lafzından çıkarılan anlamdan tümüyle farklı yönde inşa etmiştir.

Buna rağmen bahse konu hükmün, (esasen bizim de kabul ettiğimiz şekilde) lafzından anlaşıldığı hâliyle uygulanmasının, amaçlanın ötesinde ağır sonuçlar doğurduğu savunulabilir. Ancak bu noktada savunulabilecek en akılcı çözümün, yerleşik Yargıtay uygulamasında kabul edilen münhasırlık ölçütünün devam ettirilmesi olduğu kanaatinde değiliz. Bu noktada, konunun benzerliği de dikkate alındığında, 2015 tarihli İngiliz Sigorta Kanunu'nun (Insurance Act 2015) sigortalı taahhütleri (warranties) hakkında sevk edilmiş olan $10 \mathrm{vd}$. maddelerinin Türk sigorta hukuku sistemine adapte edilebileceği düşüncesindeyiz.

İngiliz sigorta hukukunda 18 'inci yüzylldan beri kabul edilmekte olan sigortalı taahhütleri, esasen rizikonun kapsam ve mahiyetine ilişkin olup, sigortalının sigorta himayesinin devamı için riayet etmesi gereken taahhütlerdir $^{49}$. Butaahhütleri esasen sigortacının sigortahimayesi sağlamasının ön şartları olarak nitelendirebilmemiz de pekâlâ mümkündür. Sigortalının sözleşmeyle hüküm altına alınan bu mahiyetteki taahhütlere harfiyen riayet etmesi (strictly compliance) gerekmektedir. 1906 tarihli Deniz Sigortaları Kanunu'nun (Marine Insurance Act 1906) 33'üncü maddesinin üçüncü fikrasında sigortalının poliçede gösterilen bu taahhütlere riayet etmemesinin müeyyidesi, sigorta teminatının ihlâlin devam ettiği süre için askıya alınması olarak düzenlenmiştir. Buna göre, taahhütlerin ihlâl edildiği süre zarfında gerçekleşen rizikoya dolayısıyla sigortacının herhangi bir sorumluluğundan söz edilememektedir. Üstelik sigortacının bu süre zarfinda gerçekleşen zarardan sorumlu olmayacağından söz edilebilmesi için vâki riziko ile taahhüdün ihlâli arasında herhangi illiyet bağı olması şartı da aranmamaktadır. Söz gelimi, geminin denize elverişliliği (seaworthiness) sözleşmede bir taahhüt olarak düzenlenmişse, geminin denize elverişlilik kriterine uygunluk sağlamadığ 1 süreler için sigorta teminatı da kesintiye uğramış olacaktır ${ }^{50}$. Bu süre zarfında gemi, denize elverişlilikle ilgisi bulunmayan bir riziko dolayısıyla zarar görecek olsa dahi, sigortacı söz konusu zararı tazminle mükellef olmayacaktır.

49 Gürses, s. 107 vd; Peter MacDonald Eggers, "The Past and Future of English Insurance Law: Good Faith and Warranties", 2012, 1(2), UCL Journal of Law and Jurisprudence, s. 237.

50 Gürses, s. 114. 
Görüldüğü üzere, sigortalı taahhütlerine yönelik yukarıda ortaya koymuş olduğumuz düzenlemeler, bilhassa sonuçları itibariyle çalışmamızın konusunu teşkil eden ilgili genel şart hükmünü çağrışmaktadır. İngiliz doktrininde, sigortalı taahhütlerine ilişkin müeyyidenin son derece ağır olduğu yıllardan bu yana dile getirilmiş, ihlâle ilişkin sonuçların sigortalılar lehine bir nebze olsun hafifletilmesi gerektiği savunulmuştur ${ }^{51}$. Netice itibariyle 12 Ağustos 2016 tarihi itibariyle yürürlüğe girmiş bulunan 2015 tarihli İngiliz Sigorta Kanunu, 1906 tarihli Deniz Sigortaları Kanunu'nun sigortalı taahhütlerine dair eleştirilere maruz kalan katı hükümlerinden bazılarını ilga etmiş ve sigortalı taahhütleri bakımından cari olan 11'inci madde hükmünü sevk etmiştir. Söz konusu maddenin ikinci ve üçüncü fikraları uyarınca sigortalı, söz konusu taahhüde harfiyen riayet etmiş olsaydı dahi zararın gerçekleşeceğini ispat edebilirse, sigortacı taahhüdün yerine getirilmemiş olduğu gerekçesiyle zararı ödemekten imtina edemeyecektir.

2015 tarihli İngiliz Sigorta Kanunu ile İngiliz sigorta hukuku bakımından cari olan sigortalı taahhütleri hakkında getirilmiş olan bu yeni düzenlemenin, Türk sigorta hukukunda riziko ile ihlâl arasında bağlantı kurulmayan teminat dışı kalan haller bakımından da benimsenebileceğini, bu sayede teminat dış1 kalan hallere ilişkin katı düzenlemenin hakkaniyete uygun olacak şekilde yeniden düzenlenmiş olacağı kanaatindeyiz. Söz konusu düzenlemeyi çalışmamızın konusunu teşkil eden Kara Araçları Kasko Sigortası Genel Şartları'nın A.5. maddesinin 5.5. bendine uyarladığımızda ortaya çıkan sonuç şöyle olacaktır: Aynı zamanda araç sürücüsü olan sigortalının yasal sınırı aşan düzeyde alkollü araç kullandığı sırada meydana gelen zararlar sigortacı tarafından karşılanmayacaktır; meğerki, sigortalı, hiç alkol almamış olsaydı dahi söz konusu zararın gerçekleşeceğini ispat edebilmiş olsun ${ }^{52}$. Böylelikle Türk Borçlar Hukukunda kusursuz sorumluluk hâlleri için öngörülmüş bulunan kurtuluş kanıtı (beyyinesi) getirme imkânı, sigorta teminatının dışında kalan hâller bakımından sigortalılara da tanınmış olacaktır. Bu sayede, bir taraftan teminat dışı kalan hâllerin uygulama itibariyle hakkaniyete aykırı sonuçlar ortaya çıkarması engellenirken, diğer taraftan teminat dışı kalan hâllerin sevk edilmesine âmil olan amacın tümüyle dışına çıkılan uygulamaların da önüne geçilebilecektir. Mamafih, teminat dışı kalan hâller bakımından sigortalılara kurtuluş kanıtı getirme imkânının hukukî manada dayanak bulabilmesi adına

\footnotetext{
51 Merkin / Gürses, s. 1016 vd.

52 Doktrinde Karasu, yürürlükte bulunan mevzuat hükümlerinde bir değişikliğe gidilmeksizin de bu yöntemin uygulanabileceği yönünde görüş serdetmektedir. Bkz. Karasu, s. 118.
} 
Kara Araçları Kasko Sigortası Genel Şartları ve Yürürlükte Bulunan Mevzuat...

bu yönde kanunî bir düzenlemeye ihtiyaç olduğu kanaatindeyiz. Aksi halde bu yönde bir uygulama, tıpkı konuya ilişkin yerleşik Yargıtay uygulaması gibi kanunî dayanaktan yoksun bir uygulama hâline gelecektir.

\section{SONUÇ}

Kara Araçları Kasko Sigortası Genel Şartları'nın A.5. maddesinin 5.5 bendinde öngörülmüş bulunan, alkollü araç kullanımı sırasında meydana gelen zararların sigorta teminatı kapsamı dışında kalacağına dair hükmün 6102 sayılı Türk Ticaret Kanunu'nun altıncı kitabında yer alan sigorta hukukuna ilişkin hükümler ve 2918 sayılı Karayolları Trafik Kanunu'nun ilgili hükümleri nazarında Kanuna uygun olduğu kanaatindeyiz. Bu anlamda Yargıtay'ın ilgili genel şart hükmüne dair, hükmün lafzıyla bağdaşmayan yerleşik uygulamasının isabetli ve hatta Kanuna uygun olduğu kanaatinde değiliz.

İlgili genel şart hükmü 6102 say1lı Türk Ticaret Kanunu'nun sigorta teminatının kapsamını tayin eden 1409'uncu maddesi hükmü çerçevesinde değerlendirilmesi, buna karşıllı aynı Kanunun 1449'uncu maddesi anlamında sözleşmesel bir görev olarak nitelendirilemeyeceği görüşündeyiz. Buna göre, alkollü araç kullanımı sırasında meydana gelen zararlar, yalnız kaza münhasıran aracın alkollü kullanılmasından ileri gelmiyor olsa bile teminat kapsamı dışında bırakılabilecektir. Üstelik ilgili genel şart hükmünün Kanuna uygunluğunun yanı sıra, korunmaya değer menfaatler bakımından adaletsiz bir sonuç ortaya çıkarmadığı düşüncesindeyiz. Buna karşılık, konuya ilişkin yerleşik Yargıtay uygulamalarında tesadüf ettiğimiz 'münhasırlık ölçütünün' alkollü araç kullanımına ilişkin caydırıcılık işlevini haiz olan ilgili genel şart hükmünü kullanılamaz hale getirdiği, bu yönüyle alkollü araç kullanımına dair Kanuna aykırı pratiği destekleyici bir mahiyet taşıdığı ve bu itibarla alkollü araç kullanan sigorta ettirenin/sigortalının korunması pahasına üçüncü kişilerin ve diğer poliçe sahiplerinin menfaatlerinin tehlikeye atıldığı aşikârdır. Üstelik 'münhasırlık ölçütünün' doğru sonuç vermekten uzak, muğlak ve şaibeli bir ölçüt olduğu yönünde çok ciddi endişeler taşımaktayız.

Sonuç olarak, ilgili genel şart hükmünün yürürlükte bulunan mevzuat hükümleri kapsamında lafzıyla hemahenk olacak şekilde uygulanması gerektiğini düşünmekle beraber, hükmün hakkaniyete aykırı sonuçlar da doğurabileceğine dair kaygıları gidermek adına bir çözüm önerisi olarak, 2015 tarihli İngiliz Sigorta Kanunu'nda olduğu gibi kurtuluş kanıtı getirme imkânının benimsenebileceğini düşünüyoruz. 


\section{KAYNAKÇA}

Arseven H, Sigorta Hukuku, Beta Yayınevi, 1991.

Bozer A, Sigorta Hukuku, BTHAE Yayınevi, 1965.

Can M, Sigorta Hukuku Ders Kitabı, Genişletilmiş ve Gözden Geçirilmiş Üçüncü Bası, İmaj Yayınevi, 2009.

Can M, "Gözden Geçirilmeye Muhtaç Hükümler Var Mı?" Sorusu Çerçevesinde 6102 Sayılı Türk Ticaret Kanunu Hükümlerine Göre Sigorta Sözleşmesinin Tabi Olduğu Hukukî Esaslar, İmaj Yayınevi, 2011.

Çetin A / Alpay S, "Sigorta Hileleri, Türk Sigorta Sektörüne Yönelik Bir Değerlendirme", 2019, 2, Management and Political Science Review, s. 7-28.

Eggers P M, "The Past and Future of English Insurance Law: Good Faith and Warranties", 2012, 1(2), UCL Journal of Law and Jurisprudence, s. 211244.

Franko N, "Sigorta Akdinde Rizikonun Ağırlaşması", Ticaret Hukuku ve Yargitay Kararları Sempozyumu, 1992, 9, s. 99-118.

Gürses Ö, Marine Insurance Law, Second Edition, Routledge, 2017.

İmre Z, "Sigorta Hukukunda Rizikonun Ağırlaşması”, 1946, 12(1), İstanbul Hukuk Mecmuasi, s. 280-301.

Karasu R, Yargıtay ve Sigorta Tahkimi İtiraz Hakem Heyeti Kararları Işı ğında Karayolları Zorunlu Malî Sorumluluk Sigortas1 (Trafik Sigortas1), Yetkin Yayınları, 2016.

Kayıhan Ş / Bağcı Ö, Türk Özel Sigorta Hukuku Dersleri, Umuttepe Yayınevi, 2018.

Kender R, Türkiye'de Hususî Sigorta Hukuku, Güncelleştirilmiş On Altıncı Baskı, On İki Levha Yayınc1lık, 2017.

Light, D A, "Sigorta Sözleşmeleri Süresi İçerisinde Sigorta Ettirenin Yükümlülükleri”, 2012, 11(22), İstanbul Ticaret Üniversitesi Sosyal Bilimler Dergisi, 10. Yıl’a Armağan, s. 1-8.

Merkin R / Gürses Ö, “The Insurance Act: 2015, Rebalancing the Interests of Insurer and Assured", 2015, 78 (6), The Modern Law Review, s. 1004- 
Kara Araçları Kasko Sigortası Genel Şartları ve Yürürlükte Bulunan Mevzuat...

1027.

Misili S, "Karayolları Motorlu Araçlar Zorunlu Malî Sorumluluk Sigortası Genel Şartları Uyarınca Sigortacının Sigorta Ettirene Rücu Davası", 2017, 133, Türkiye Barolar Birliği Dergisi, s. 577-648.

Seven V, “Alkollü Araç Kullanma İle İlgili Karayolları Trafik Kanunu'nda Yapılan Değişikliğin Sigorta Şirketinin İspat Yüküne Etkisi”, 2016, 22(3), Cevdet Yavuz'a Armağan, Marmara Üniversitesi Hukuk Fakültesi Hukuk Araştırmaları Dergisi, s. 2521-2530.

Ünan S, "Yargitay 17. Hukuk Dairesi’nin Araç Üzerindeki Rehin, Alkollü Araç Kullanılması ve Araçtaki Değer Kaybı" Sorunlarını Ele Alan Kara Araçları Kasko Sigortası ile İlgili 02.05.2013 Gün ve 2013/19986148 Sayılı Kararının Değerlendirilmesi”, 2013, 27, Ticaret Hukuku ve Yargitay Kararları Sempozyumu, s. 112-155.

Ünan S, "Sözleşmesel Görevler (TTK 1449)", 2014 (28), Ticaret Hukuku ve Yargitay Kararları Sempozyumu, s. 11-37.

Yazıcıoğlu E, "Zarar Sigortalarında Sigorta Himayesinin Sınırlandırılması ve Davranış Yükümlülüklerinin Teminat Şartı ya da İstisna Olarak Öngörülmesi Sorunu", Prof. Dr. Ergon A. Çetingil ve Prof. Dr. Rayegân Kender'e 50. Yı1 Birlikte Çalışma Armağanı, 2007, s. 1185-1194. 